\title{
Yttrium Methanide and Methanediide Bis(silyl)amide Complexes
}

DOI:

10.1021/acs.organomet.7b00394

\section{Document Version}

Accepted author manuscript

Link to publication record in Manchester Research Explorer

\section{Citation for published version (APA):}

Ortu, F., Gregson, M., Wooles, A., Mills, D., \& Liddle, S. (2017). Yttrium Methanide and Methanediide

Bis(silyl)amide Complexes. Organometallics. https://doi.org/10.1021/acs.organomet.7b00394

\section{Published in:}

Organometallics

\section{Citing this paper}

Please note that where the full-text provided on Manchester Research Explorer is the Author Accepted Manuscript or Proof version this may differ from the final Published version. If citing, it is advised that you check and use the publisher's definitive version.

\section{General rights}

Copyright and moral rights for the publications made accessible in the Research Explorer are retained by the authors and/or other copyright owners and it is a condition of accessing publications that users recognise and abide by the legal requirements associated with these rights.

\section{Takedown policy}

If you believe that this document breaches copyright please refer to the University of Manchester's Takedown Procedures [http://man.ac.uk/04Y6Bo] or contact uml.scholarlycommunications@manchester.ac.uk providing relevant details, so we can investigate your claim.

\section{OPEN ACCESS}


- Submission to Organometallic Actinide and Lanthanide Chemistry Issue -

\section{Yttrium Methanide and Methanediide Bis(silyl)amide Complexes}

Fabrizio Ortu, Matthew Gregson, Ashley J. Wooles, David P. Mills* and Stephen T. Liddle*

School of Chemistry, The University of Manchester, Oxford Road, Manchester, M13 9PL, U.K.

ABSTRACT: The yttrium methanediide complex $\left[Y(B I P M)(I)(T H F)_{2}\right] \quad(B I P M=$ $\left.\left\{\mathrm{C}\left(\mathrm{PPh}_{2} \mathrm{NSiMe}_{3}\right)_{2}\right\}\right)$ was reacted with a series of potassium bis(silyl)amides to produce heteroleptic complexes by salt metathesis protocols. The methanediide complexes, $\left[Y(B I P M)\left(N^{\prime \prime}\right)(T H F)\right]\left(1, N^{\prime \prime}\right.$ $\left.=\left\{N\left(\mathrm{SiMe}_{3}\right)_{2}\right\}\right)$ and $\left[Y(\mathrm{BIPM})\left(N^{* *}\right)(\mathrm{THF})\right]\left(2, N^{* *}=\left\{N\left(\mathrm{SiMe}_{2}{ }^{t} \mathrm{Bu}\right)_{2}\right\}\right)$ were obtained for those relatively small bis(silyl)amides. Complex 2 undergoes thermal decomposition under vacuum to yield the methanide cyclometalate complex $\left[Y(H-B I P M)\left\{N\left(S i^{t} B u M e_{2}\right)\left(S i^{t} B u M e C H_{2}\right)-\kappa^{2}-N, C\right\}\right]$ as part of an otherwise intractable mixture of products. Complex 3 was also observed in trace amounts in mixtures of $\left[Y(B I P M)(I)(T H F)_{2}\right]$ and $K N^{* *}$. In contrast, $\left[Y(B I P M)(I)(T H F)_{2}\right]$ reacted with the more sterically demanding potassium bis(silyl)amides $\mathrm{KN}^{*{ }^{\dagger}}\left(N^{*{ }^{\dagger}}=\left\{N\left(\mathrm{SiMe}_{2}{ }^{t} \mathrm{Bu}\right)\left(\mathrm{Si}^{i} \mathrm{Pr}_{3}\right)\right\}\right)$ and $K N^{\dagger \dagger}\left(N^{\dagger \dagger}=\left\{N\left(S^{i} \operatorname{Pr}_{3}\right)_{2}\right\}\right)$ to afford the methanide cyclometalate complexes, [Y $(H-$ $\left.\left.B I P M)\left\{N\left(S i^{i} \mathrm{Pr}_{3}\right)\left(\mathrm{Si}^{t} \mathrm{BuMeCH} \mathrm{H}_{2}\right)-\kappa^{2}-\mathrm{N}, \mathrm{C}\right)\right\}\right]$ (4) and $\left[Y(\mathrm{H}-\mathrm{BIPM})\left\{\mathrm{N}\left(\mathrm{Si}^{i} \mathrm{Pr}_{3}\right)\left[\mathrm{Si}^{i} \mathrm{Pr}_{2}\left(\mathrm{CHMeCH}_{2}\right)\right]-\kappa^{2}-\right.\right.$ N,C\}] (5), respectively. Complexes 1-5 were characterized as appropriate by multinuclear NMR and FTIR spectroscopy, elemental analyses and single crystal X-ray diffraction. 


\section{INTRODUCTION}

Lanthanide ( $\mathrm{Ln})$ bonding regimes are predominantly electrostatic, thus the coordination numbers and shapes of lanthanide complexes are largely dictated by ligand steric effects. ${ }^{1}$ Since structural features can influence useful physicochemical properties, lanthanide complexes with specific geometries have been targeted and synthesized using judiciously selected ligands. ${ }^{2}$ Recently, late lanthanide complexes with large magnetic anisotropy have become synthetic goals as these are predicted to provide the best-performing Single-Molecule Magnets (SMMs). ${ }^{3-4}$ Depending upon the identity of the $\operatorname{Ln}(\mathrm{III})$ ion, axial or equatorial ligand charge distributions give ideal SMM properties; for oblate Dy(III), axial systems are preferred and the largest magnetic anisotropies to date have been achieved by placing all anionic ligand heteroatoms on a single molecular axis. ${ }^{5-9}$ Thus, linear 2-coordinate Dy(III) SMMs are synthetic targets as they are predicted to give the largest possible magnetic anisotropies. ${ }^{10-13}$ However, such geometries and coordination numbers are currently unknown for $\operatorname{Ln}(\mathrm{III})$ complexes, which is unsurprising given the synthetic challenges associated with achieving low coordination numbers in lanthanide chemistry. ${ }^{1}$

Given the difficulties associated with synthesizing 2-coordinate Ln(III) complexes, highly axial $\operatorname{Ln}(\mathrm{III})$ systems with weakly coordinating equatorial donor atoms were first targeted. Some of us recently reported the bis(methanediide)-Dy(III) complex $\left[\mathrm{K}(18 \mathrm{C} 6)(\mathrm{THF})_{2}\right]\left[\mathrm{Dy}(\mathrm{BIPM})_{2}\right]($ Figure $1,18 \mathrm{C} 6=18$-crown-6; $\left.\mathrm{BIPM}=\left\{\mathrm{C}\left(\mathrm{PPh}_{2} \mathrm{NSiMe}_{3}\right)_{2}\right\}\right)$, which exhibits a relatively large barrier to the reversal of magnetization $\left(U_{\text {eff }}=813 \mathrm{~K}\right)$ as it has a highly axial charge distribution (effectively a $\mathrm{C}^{2-}$ $=\mathrm{Dy}^{3+}=\mathrm{C}^{2-}$ axis with four off-equatorial N-donors $){ }^{5}$ As increased $U_{\text {eff }}$ values are expected to result from increased ligand charge axiality for Dy(III), ${ }^{10-13}$ we reasoned that reducing the number of equatorial donor atoms should give larger energy barriers and improved SMM properties. Since Cavell's landmark discovery of $\left[\mathrm{Sm}(\mathrm{BIPM})\left(\mathrm{NCy}_{2}\right)(\mathrm{THF})\right],{ }^{14}$ a number of heteroleptic Ln(III) BIPM complexes have been reported, but none have been prepared to date with monodentate co-ligands of sufficient steric bulk to prevent the presence of equatorially-coordinated solvent molecules. ${ }^{15}$ Notably, mixed dianion-amide complexes of Sc have been reported by Mézailles and co-workers by 
employing the closely related chelating $\left\{\mathrm{C}\left(\mathrm{PPh}_{2} \mathrm{~S}\right)_{2}\right\}^{2-}$ ligand, and also in this case coordination of solvent molecules was observed. ${ }^{16}$ Some of us have recently reported a new series of bis(silyl)amides; ${ }^{17}$ the steric properties of these systems have been demonstrated by the isolation of the first near-linear $\mathrm{Ln}(\mathrm{II})$ complexes, $\left[\mathrm{Ln}\left(\mathrm{N}^{\dagger \dagger}\right)_{2}\right]\left(\right.$ Figure $1, \mathrm{~N}^{\dagger \dagger}=\left\{\mathrm{N}\left(\mathrm{Si}^{i} \mathrm{Pr}_{3}\right)_{2}\right\} ; \mathrm{Ln}=\mathrm{Sm},{ }^{11} \mathrm{Eu}, \mathrm{Tm}$, $\left.\mathrm{Yb}^{18}\right)$, a trigonal-planar actinide complex, $\left[\mathrm{U}\left(\mathrm{N}^{* *}\right)_{3}\right]\left(\mathrm{N}^{* *}=\left\{\mathrm{N}\left(\mathrm{Si}^{t} \mathrm{Bu} \mathrm{Me}_{2} \mathrm{Me}\right\}\right),{ }^{19}\right.$ and a trigonalplanar Tm(II) complex, $[\mathrm{K}(2.2 .2$-cryptand $)]\left[\mathrm{Tm}\left(\mathrm{N}^{* *}\right)_{3}\right] .{ }^{20}$ We envisaged that a heteroleptic Dy(III) complex containing both $\mathrm{BIPM}$ and a suitable bis(silyl)amide, $\mathrm{N}^{\mathrm{RR}}\left(\mathrm{R} / \mathrm{R}^{\prime}=\mathrm{SiMe}_{3}, \mathrm{Si}^{t} \mathrm{BuMe}_{2}\right.$ or $\left.\mathrm{Si}^{i} \mathrm{Pr}_{3}\right)$, might give solvent-free $\left[\mathrm{Dy}(\mathrm{BIPM})\left(\mathrm{N}^{\mathrm{RR}}\right)\right]$, which would contain only two equatorial $\mathrm{N}-$ donors and thus should have a large $U_{\text {eff }}$ value. The largest of these bis(silyl)amides, $\mathrm{N}^{\dagger \dagger}$, was considered to have the greatest chance of success, thus the combination of $\mathrm{Ln}^{3+}, \mathrm{BIPM}$ and $\mathrm{N}^{\dagger \dagger}$ presents the prime synthetic targets, $\left[\operatorname{Ln}(\mathrm{BIPM})\left(\mathrm{N}^{\dagger \dagger}\right)\right]$ (Figure 1). We decided to also investigate smaller bis(silyl)amides to probe the amount of steric bulk required for exclusion of coordinating solvents from the $\operatorname{Ln}(\mathrm{III})$ coordination sphere.

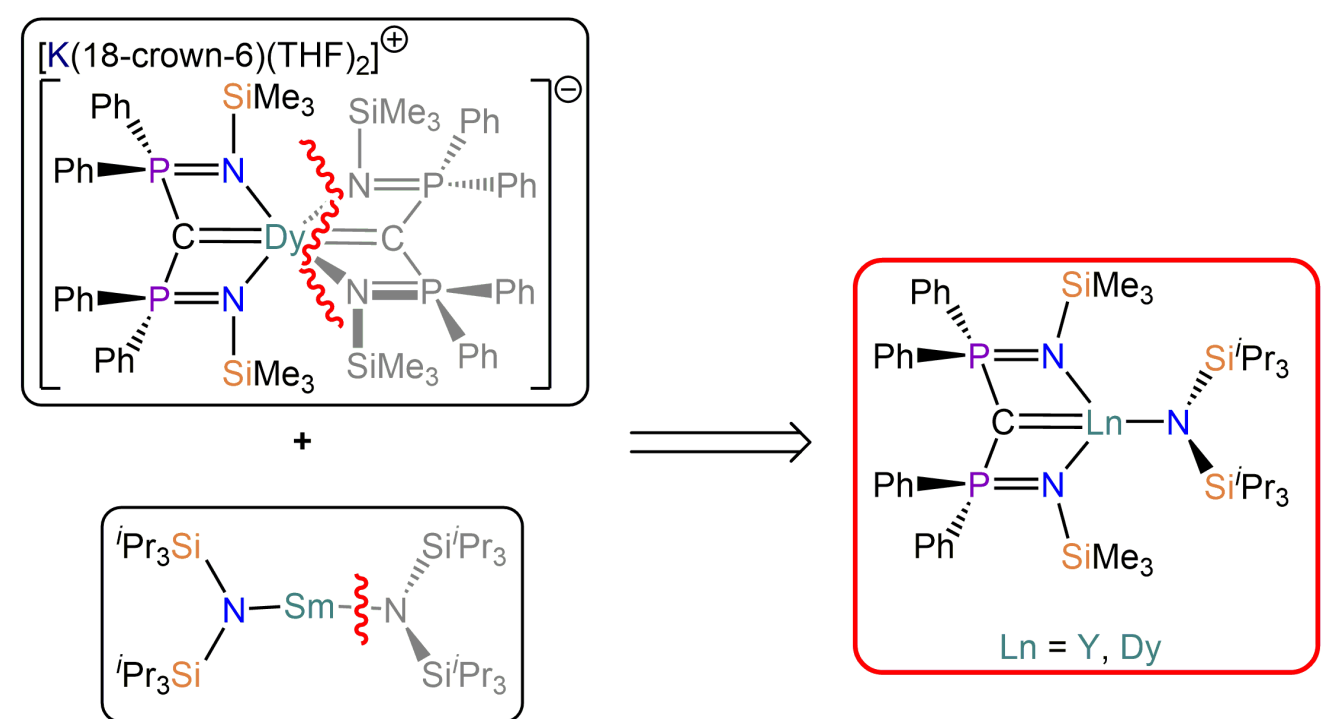

Figure 1. Combination of the ligands in homoleptic $\left[\mathrm{K}(18 \mathrm{C} 6)(\mathrm{THF})_{2}\right]\left[\mathrm{Dy}(\mathrm{BIPM})_{2}\right]$ and $\left[\mathrm{Sm}\left(\mathrm{N}^{\dagger \dagger}\right)_{2}\right]$ to give the prime heteroleptic synthetic targets, $\left[\operatorname{Ln}(\mathrm{BIPM})\left(\mathrm{N}^{\dagger \dagger}\right)\right](\mathrm{Ln}=\mathrm{Dy}, \mathrm{Y})$. 
Herein, we describe our efforts towards the synthesis of solvent-free $\left[\mathrm{Y}(\mathrm{BIPM})\left(\mathrm{N}^{\mathrm{RR}}\right)\right]$. In these proof-of-concept studies we used yttrium as diamagnetic $\mathrm{Y}(\mathrm{III})$ is of a similar size to $\mathrm{Dy}(\mathrm{III}),{ }^{21}$ thus it provides an ideal surrogate for testing the feasibility of comparable Dy(III) chemistry; indeed, Y(III) complexes are commonly used to produce lattices for Dy(III) dopants when analyzing SMM properties. ${ }^{3}$ We have used salt metathesis protocols as these have proven suitability for the synthesis of lanthanide bis(silyl)amide complexes, ${ }^{22}$ and $\left[\operatorname{Ln}(\mathrm{BIPM})(\mathrm{I})(\mathrm{THF})_{2}\right]^{23}$ has already been shown to be an effective starting material for heteroleptic Ln(III) BIPM complexes. $^{24-25}$

\section{RESULTS AND DISCUSSION}

\section{Synthesis and spectroscopic characterization}

We first investigated bis(silyl)amides of moderate steric bulk to determine the feasibility of our methodology. The separate reactions of $\left[\mathrm{Y}(\mathrm{BIPM})(\mathrm{I})(\mathrm{THF})_{2}\right]$ with $\mathrm{KN}^{\prime \prime}\left(\mathrm{N}^{\prime \prime}=\left\{\mathrm{N}\left(\mathrm{SiMe}_{3}\right)_{2}\right\}\right)$ and $\mathrm{KN}^{* *}$ gave the respective $\mathrm{Y}(\mathrm{III})$ methanediide complexes, $\left[\mathrm{Y}(\mathrm{BIPM})\left(\mathrm{N}^{\mathrm{RR}}\right)(\mathrm{THF})\right]\left[\mathrm{N}^{\mathrm{RR}}=\mathrm{N}^{\prime \prime}(\mathbf{1})\right.$; $\mathrm{N}^{\mathrm{RR}}=\mathrm{N}^{* *}(\mathbf{2})$ ], in good yields (Scheme 1). Whilst the ${ }^{1} \mathrm{H}$ NMR spectra of 1-2 are unremarkable, their ${ }^{13} \mathrm{C}\left\{{ }^{1} \mathrm{H}\right\}$ NMR spectra contain distinctive doublet of triplet signals for the methanediides due to ${ }^{31} \mathrm{P}$ and ${ }^{89} \mathrm{Y}$ coupling $\left(\mathbf{1}: \delta_{\mathrm{C}}=57.85, J_{\mathrm{CP}}=180 \mathrm{~Hz}, J_{\mathrm{CY}}=5 \mathrm{~Hz} ; 2: \delta_{\mathrm{C}}=63.37, J_{\mathrm{CP}}=166 \mathrm{~Hz}, J_{\mathrm{CY}}=\right.$ $8 \mathrm{~Hz})$, and ${ }^{89} \mathrm{Y}$ coupling is observed in their ${ }^{31} \mathrm{P}\left\{{ }^{1} \mathrm{H}\right\}$ NMR spectra $\left(\mathbf{1}: \delta_{\mathrm{P}}=5.50, \mathrm{~d},{ }^{2} J_{\mathrm{PY}}=15 \mathrm{~Hz} ; \mathbf{2}\right.$ : $\left.\delta_{\mathrm{P}}=7.55, \mathrm{~d},{ }^{2} J_{\mathrm{PY}}=15 \mathrm{~Hz}\right)$. These resonances are comparable to the corresponding data for $\left[\mathrm{Y}(\mathrm{BIPM})(\mathrm{I})(\mathrm{THF})_{2}\right]\left(\delta_{\mathrm{C}}=60.28, J_{\mathrm{CP}}=207 \mathrm{~Hz}, J_{\mathrm{CY}}=5 \mathrm{~Hz} ; \delta_{\mathrm{P}}=3.48,{ }^{2} J_{\mathrm{PY}}=13 \mathrm{~Hz}\right)^{23 \mathrm{a}}$ and other complexes of the general formula $[\mathrm{Y}(\mathrm{BIPM})(\mathrm{X})(\mathrm{THF})](\mathrm{X}=$ anionic ligand $) .{ }^{25,27-29}$ Furthermore, the ${ }^{29} \mathrm{Si}\left\{{ }^{1} \mathrm{H}\right\}$ NMR spectra of $\mathbf{1 - 2}$ each exhibit signals for both the BIPM and $\mathrm{N}^{\mathrm{RR}}$ fragments $\left(\mathbf{1}: \delta_{\mathrm{Si}}=-\right.$ $\left.10.57,-9.25 ; 2: \delta_{\mathrm{Si}}=-8.11,-6.82\right)$. 


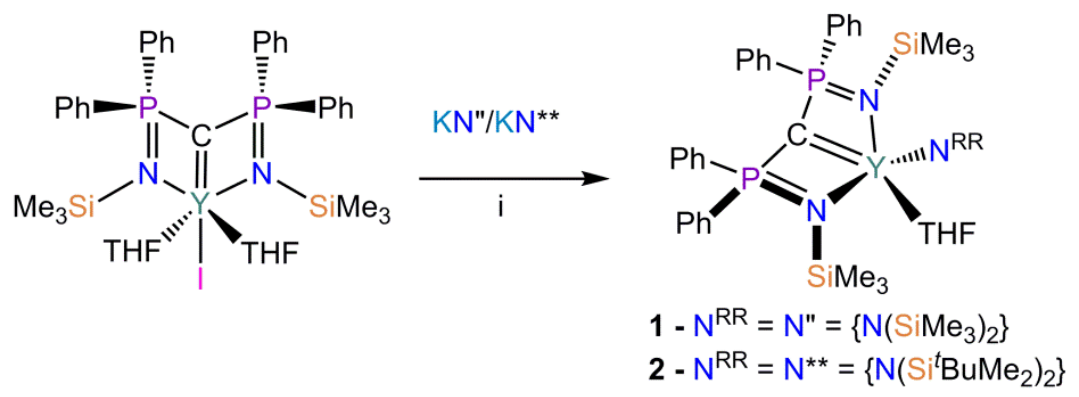

Scheme 1. Synthesis of $\left[\mathrm{Y}(\mathrm{BIPM})\left(\mathrm{N}^{\mathrm{RR}}\right)(\mathrm{THF})\right]$ complexes $\mathbf{1}$ and 2. Reaction conditions: $\mathrm{i}=$ toluene, $-78^{\circ} \mathrm{C}$ to r.t., $16 \mathrm{~h},-\mathrm{KI}$.

As the combination of BIPM and $\mathrm{N}^{* *}$ did not provide sufficient steric bulk to exclude THF from the coordination sphere of Y(III) in $\mathbf{2}$, we attempted to remove the solvent by heating a solid sample in vacuo $\left(90{ }^{\circ} \mathrm{C}, 10^{-2} \mathrm{mbar}\right.$, ramp rate $+10{ }^{\circ} \mathrm{C} / \mathrm{hr}, 8 \mathrm{hrs}$; see Supporting Information for further details). Analysis of the ${ }^{31} \mathrm{P}\left\{{ }^{1} \mathrm{H}\right\}$ NMR spectra of the resultant solid revealed that 2 was still present, together with a small quantity of the pro-ligand $\mathrm{H}_{2}$-BIPM and at least one other phosphorus-containing species $\left(\delta_{\mathrm{P}}=10.05\right.$, at, ${ }^{2} J_{\mathrm{PY}}=6 \mathrm{~Hz} ; 19.89$, br m; $\left.21.97, \mathrm{~d},{ }^{2} J_{\mathrm{PY}}=6 \mathrm{~Hz}\right)$ (Figure 2). The low field chemical shifts and relatively small ${ }^{2} J_{\mathrm{PY}}$ values of the new species are indicative of the formation of a complex containing a monoprotonated ligand (H-BIPM), with the backbone carbon formally bearing a single negative charge e.g. methanide. ${ }^{23-26}$ In addition, the ${ }^{13} \mathrm{C}\left\{{ }^{1} \mathrm{H}\right\}$ NMR spectrum of this mixture contains a triplet $\left(\delta_{\mathrm{C}}=19.79, J_{\mathrm{CP}}=91 \mathrm{~Hz}, J_{\mathrm{CY}}\right.$ not resolved) that we tentatively assign as a Y(III) methanide resonance based on the similarity of the chemical shift and $J_{\mathrm{CP}}$ coupling constant to other Y(III) H-BIPM complexes. ${ }^{23-26} \mathrm{VT}{ }^{1} \mathrm{H}$ and ${ }^{31} \mathrm{P}\left\{{ }^{1} \mathrm{H}\right\}$ NMR experiments were carried out to assess the thermal stability of 2 in $d_{6}$-benzene from 298-333 K in $5 \mathrm{~K}$ intervals (see Supporting Information). No new signals of significant intensity were observed, indicating that the loss of coordinated THF may be a key step in the decomposition of 2. 


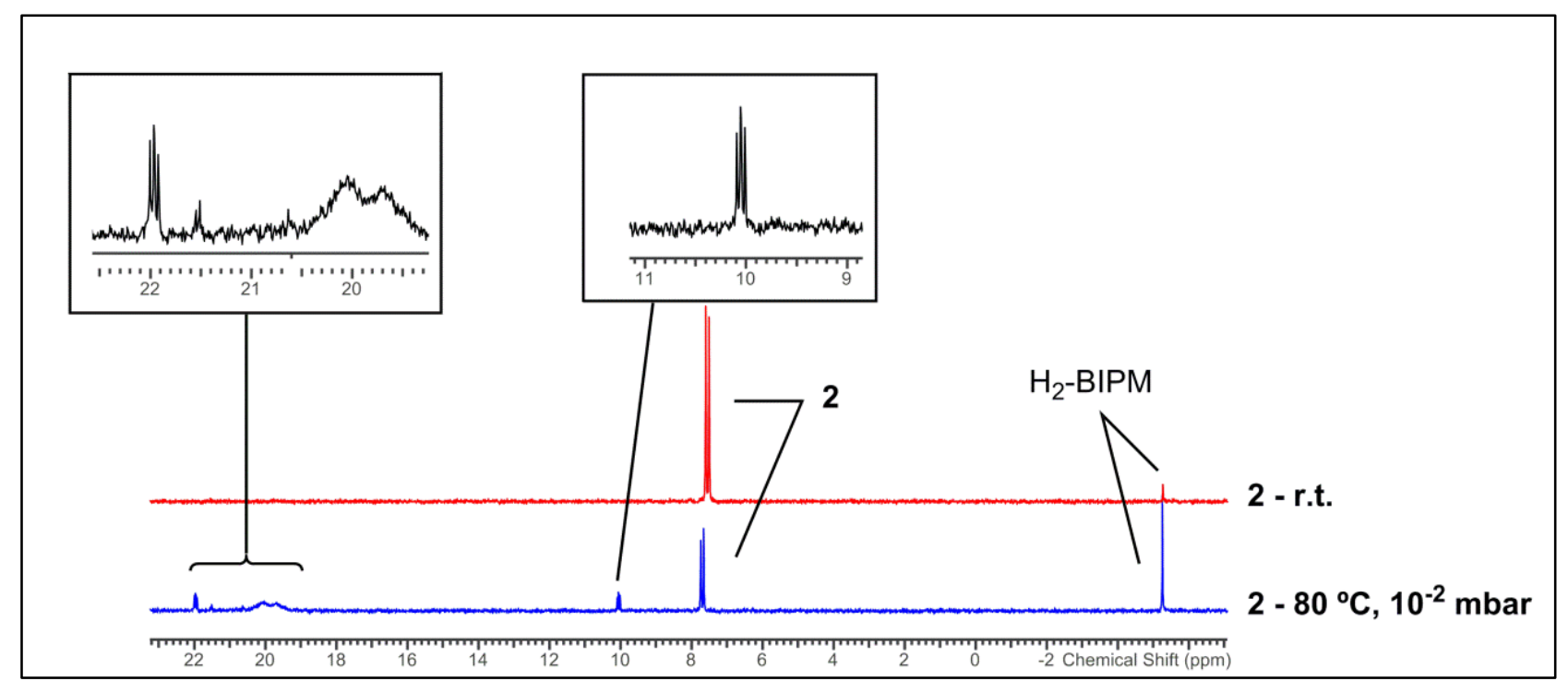

Figure 2. ${ }^{31} \mathrm{P}\left\{{ }^{1} \mathrm{H}\right\}$ NMR spectra ( $d_{6}$-benzene) of $\mathbf{2}$ (top) and a solid sample of $\mathbf{2}$ heated in vacuo (r.t. $>90{ }^{\circ} \mathrm{C}, 10^{-2}$ mbar, ramp rate $\left.+10^{\circ} \mathrm{C} / \mathrm{hr}, 8 \mathrm{hrs}\right)$.

The synthesis of $\mathbf{2}$ was repeated in an effort to identify one of the yttrium-containing byproducts, and on this occasion the reaction mixture was extracted with hot hexane (see Supporting Information for full details). These harsher work-up conditions lead to the formation of crystals of the cyclometalated methanide complex, [Y(H-BIPM) $\left.\left\{\mathrm{N}\left(\mathrm{Si}^{\mathrm{i}} \mathrm{Pr}_{3}\right)\left(\mathrm{Si}^{\mathrm{t}} \mathrm{BuMeCH}_{2}\right)-\kappa^{2}-N, C\right\}\right]$ (3), together with other, amorphous, products (Scheme 2). The ${ }^{1} \mathrm{H},{ }^{13} \mathrm{C}\left\{{ }^{1} \mathrm{H}\right\}$ and ${ }^{31} \mathrm{P}\left\{{ }^{1} \mathrm{H}\right\} \mathrm{NMR}$ spectra of this product mixture indicated the presence of $2, \mathrm{H}_{2}-\mathrm{BIPM}$ and $\left[\mathrm{Y}(\mathrm{H}-\mathrm{BIPM})(\mathrm{I})_{2}(\mathrm{THF})\right]^{24}$ by comparison with authentic samples, precluding confident assignment of the resonances due to 3 . Cyclometalation is a common occurrence in early metal silylamide chemistry, particularly for complexes with coordinatively unsaturated metal centers, ${ }^{22}$ since negative hyperconjugation to the silicon atom stabilizes the resulting carbanion. ${ }^{30}$ This process is likely facilitated by the increased Lewis acidity of Y(III) following the dissociation of THF, which may be promoted by the combined steric effects of BIPM and $\mathrm{N}^{* *}$. We note, also, that yttrium-BIPM complexes have previously shown themselves to be proficient at effecting $\mathrm{C}-\mathrm{H}$ activation/deprotonation of the ortho-CH of aryl ketones where the BIPM methanediide is converted to a methanide so the methanediide centers in yttrium-BIPM complexes are clearly rather basic. ${ }^{25}$ Lappert and co-workers have previously shown that steric effects play a crucial role in the self-deprotonation of bulky diketiminate ligands. ${ }^{31}$ Also, 
it has been previously observed that both intra- and intermolecular processes can operate in the deprotonation of silylamides. ${ }^{32}$ Indeed, in our study we observed the presence of $\mathrm{H}_{2}-\mathrm{BIPM}$ in the NMR spectra, but we were not able to unequivocally identify the proton transfer process in action.

With our methodology established, we then investigated bis(silyl)amides of larger steric bulk. The separate reactions of $\left[\mathrm{Y}(\mathrm{BIPM})(\mathrm{I})(\mathrm{THF})_{2}\right]$ with $\mathrm{KN}^{*^{\dagger}}\left(\mathrm{N}^{*^{\dagger}}=\left\{\mathrm{N}\left(\mathrm{SiMe}_{2}{ }^{t} \mathrm{Bu}\right)\left(\mathrm{Si}^{i} \mathrm{Pr}_{3}\right)\right\}\right)$ and $\mathrm{KN}^{\dagger \dagger}$ yielded the respective cyclometalated methanide complexes $[\mathrm{Y}(\mathrm{H}-$ $\left.\mathrm{BIPM})\left\{\mathrm{N}\left(\mathrm{Si}^{\mathrm{i}} \mathrm{Pr}_{3}\right)\left(\mathrm{Si}^{\mathrm{t}} \mathrm{BuMeCH}_{2}\right)-\kappa^{2}-N, C\right\}\right]$ (4) and $\left[\mathrm{Y}(\mathrm{H}-\mathrm{BIPM})\left\{\mathrm{N}\left(\mathrm{Si}^{\mathrm{i}} \mathrm{Pr}_{3}\right)\left[\mathrm{Si}^{\mathrm{i}} \mathrm{Pr}_{2}\left(\mathrm{CHCH}_{3} \mathrm{CH}_{2}\right)\right]-\kappa^{2}-\right.\right.$ $N, C\}]$ (5) in good yields (Scheme 2). The NMR spectra of both reaction mixtures did not contain any resonances that could credibly be assigned to a methanediide product, thus cyclometalation is facile for these larger bis(silyl)amides. We attribute this to the increased steric saturation about the charge dense $\mathrm{Y}(\mathrm{III})$ center in these systems, as we have previously observed cyclometalation in ytterbium $\mathrm{N}^{* *}$ chemistry. ${ }^{20}$ The ${ }^{1} \mathrm{H},{ }^{13} \mathrm{C}\left\{{ }^{1} \mathrm{H}\right\},{ }^{29} \mathrm{Si}\left\{{ }^{1} \mathrm{H}\right\}$ and ${ }^{31} \mathrm{P}\left\{{ }^{1} \mathrm{H}\right\}$ NMR spectra of isolated samples of $\mathbf{4}$ and $\mathbf{5}$ are complicated and contain multiple resonances as a result of their low symmetry coupled with potential dynamic processes in solution, making them difficult to unequivocally interpret and assign. In addition methanide signals were not observed in the ${ }^{13} \mathrm{C}\left\{{ }^{1} \mathrm{H}\right\}$ NMR spectra of $\mathbf{4}$ or $\mathbf{5}$. However, we suggest that the vast majority of NMR signals observed correspond to the products as similarly complex NMR spectra have been observed previously in fblock silylamide cyclometalates ${ }^{33,34}$ and the elemental analyses obtained for both complexes are in good agreement with calculated values. 2D-NMR experiments were used to identify the components of the cyclometalate rings in $\mathbf{4}$ and $\mathbf{5}$. The ${ }^{1} \mathrm{H}$ NMR spectra of both complexes contain complex multiplets $\left(4: \delta_{\mathrm{H}}=0.65 ; 5: \delta_{\mathrm{H}}=1.46\right)$ that we assign as the cyclometalated $\mathrm{CH}_{2}$ groups by correlation (HSQC) with doublets in their ${ }^{13} \mathrm{C}\left\{{ }^{1} \mathrm{H}\right\}$ NMR spectra $\left(\mathbf{4}: \delta_{\mathrm{C}}=36.13, J_{\mathrm{CY}}=39 \mathrm{~Hz} ; \mathbf{5}\right.$ : $\delta_{\mathrm{C}}$ $=54.35 ; J_{\mathrm{CY}}=47 \mathrm{~Hz}$ ), in agreement with $\mathrm{C}-\mathrm{Y}$ bond formation. COSY and HSQC experiments were performed to fully assign the components of the cyclometalate ring (see Supporting Information for full details), but other signals could only be tentatively assigned. 


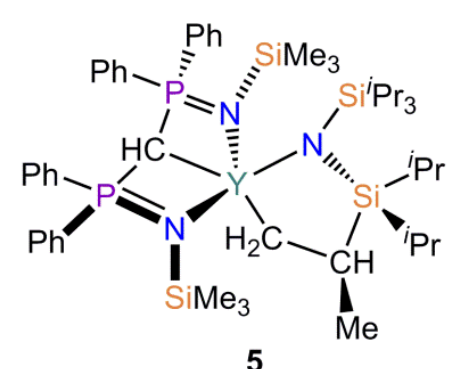
5

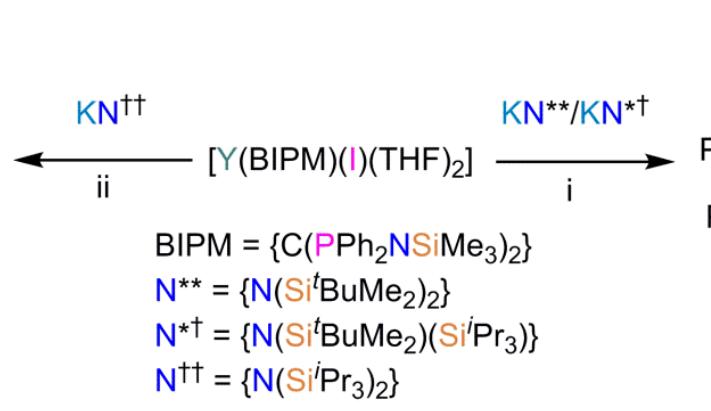

$\mathrm{N}^{\mathrm{t}}=\left\{\mathrm{N}\left(\mathrm{Si}^{i} \mathrm{Pr}_{3}\right)_{2}\right\}$

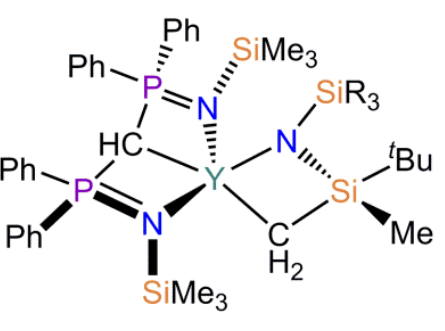

3: $\mathrm{R}_{3}={ }^{\mathrm{t}} \mathrm{BuMe}_{2}$

4: $\mathrm{R}_{3}={ }^{i} \mathrm{Pr}_{3}$

Scheme 2. Synthesis of methanide complexes 3-5. Reaction conditions: $\mathrm{i}=$ toluene, $-78{ }^{\circ} \mathrm{C}$ to r.t., $16 \mathrm{~h},-\mathrm{KI} ; \mathrm{ii}=$ toluene, $-78^{\circ} \mathrm{C}$ to r.t., $16 \mathrm{~h},-\mathrm{KI}$.

\section{Structural Characterization}

Crystals of 1-5 were obtained that proved suitable for structural determination by single crystal Xray diffraction (Figures 3-6 and Supporting Information Figure S51; bond lengths and angles are listed in Table 1). Despite repeated attempts, only poor quality datasets could be obtained for $\mathbf{1}$ so its metric parameters are not discussed, although the connectivity is clear-cut (Figure S50). It is also noteworthy that crystals of $\mathbf{5}$ formed from both benzene and toluene solutions, hence two datasets are provided. The solid state structure of $\mathbf{2}$ (Figure 3) confirms the expected connectivity around the yttrium center, comprising of tridentate BIPM, monodentate $\mathrm{N}^{* *}$ and one coordinated THF molecule (Figure 3). The $\mathrm{Y}=\mathrm{C}$ bond length $[2.357(3) \AA]$ is characteristic of a $\mathrm{Y}(\mathrm{III})$ methanediide by comparison with those distances reported for $\left[\mathrm{Y}(\mathrm{BIPM})(\mathrm{I})(\mathrm{THF})_{2}\right][2.356(3) \AA]^{23 \mathrm{a}}$ and $\left[\mathrm{Y}(\mathrm{BIPM})\left\{\mathrm{Ga}(\mathrm{NArCH})_{2}\right\}(\mathrm{THF})_{2}\right][2.348(3) \AA] .{ }^{24}$ It is noteworthy that one of the methyl groups of $\mathrm{N}^{* *}$ is relatively close to the metal center $[\mathrm{Y}(1) \cdots \mathrm{C}(38)=3.05(2) \AA]$. This asymmetry could not be observed in the ${ }^{1} \mathrm{H}$ and ${ }^{13} \mathrm{C}\left\{{ }^{1} \mathrm{H}\right\}$ NMR spectra, therefore we conclude that this interaction is weak and does not persist in solution; however, this close interaction hints at an incipient anagostic-type interaction that may be a prelude to $\mathrm{C}-\mathrm{H}$ activation/1,2-addition across the $\mathrm{Y}=\mathrm{C}$ double bond to give 3. All other metrical parameters of $\mathbf{2}$ are unremarkable and the BIPM intraligand bond lengths and angles are consistent with previously reported Y(III) BIPM complexes. ${ }^{15}$ 


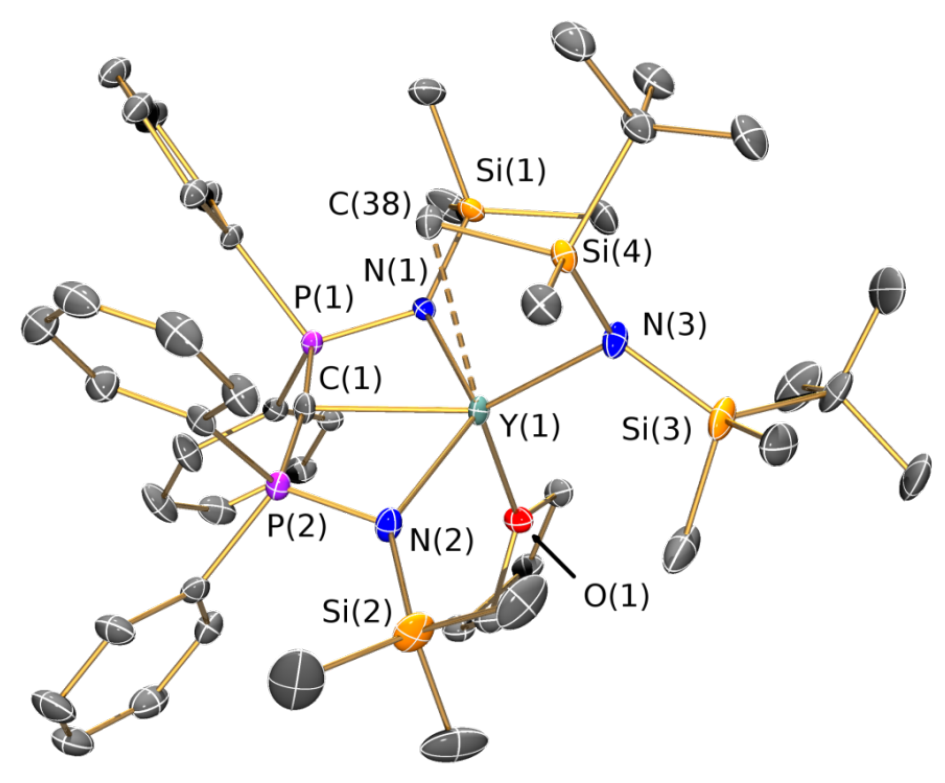

Figure 3. Molecular structure of $\mathbf{2}$ with selective atom labeling, with displacement ellipsoids set at the $30 \%$ probability level; hydrogen atoms have been omitted for clarity.

The structure of 3 (Figure 4) confirms the formation of a methanide and a 4-membered metalacycle, $C^{\wedge} Y^{\wedge} N^{\wedge} \mathrm{Si}$. The significant deviation from planarity of the pincer ligand scaffold [P-C$\left.\mathrm{P}=169.54(19)^{\circ}(2) ; \mathrm{P}-\mathrm{C}-\mathrm{P}=133.0(3)^{\circ}(3)\right]$ gives the diagnostic pseudo-boat H-BIPM conformation and the $\mathrm{Y}-\mathrm{C}_{\mathrm{H}-\mathrm{BIPM}}$ distance of 3 [2.773(5) $\AA$ ] is relatively long; $c f .2 .599(2) \AA$ for $\left[\mathrm{Y}(\mathrm{H}-\mathrm{BIPM})(\mathrm{I})_{2}(\mathrm{THF})\right] .{ }^{24}$ The cyclometalation is additionally supported by the short distance between the metal center and one of the methyl groups within the $\mathrm{SiMe}_{2}$ unit of the $\mathrm{N}^{* *}$ ligand [Y$\mathrm{C}=2.405(6) \AA]$; this is significantly shorter than the $\mathrm{Y} \cdots \mathrm{C}$ contact seen for $\mathbf{2}$ and is similar to the combined single bond covalent radii of $\mathrm{Y}$ and $\mathrm{C}(2.38 \AA ⿻) .{ }^{35}$ Complexes 4 and $\mathbf{5}$ exhibit 4$\left(C^{\wedge} Y^{\wedge} N^{\wedge} S i\right)$ and 5-membered $\left(C^{\wedge} Y^{\wedge} N^{\wedge} S i^{\wedge} C\right)$ metalacycles, respectively (Figures 5 and 6). The Y$\mathrm{C}_{\mathrm{H}-\mathrm{BIPM}}$ distances in these complexes are consistent with methanide formation [2.729(2) $\AA$ (4); 2.713(3) $\AA(5)]$, but are both shorter than those of $\mathbf{3}$. This likely results from the increased size of the $\mathrm{N}^{\mathrm{RR}}$ ligands in $\mathbf{4}$ and 5, which give relatively long $\mathrm{Y}-\mathrm{N}_{\text {silylamide }}$ bond lengths [2.267(8) $\AA$ (4); 2.281(3) $\AA$ (5)] and correspondingly shorter $\mathrm{Y}-\mathrm{C}_{\mathrm{H}-\mathrm{BIPM}}$ distances. The latter interactions are longer than those normally found for yttrium complexes with H-BIPM; ${ }^{25,36}$ however, similar distances have been previously observed for methanide heteroleptic $\mathrm{Y}(\mathrm{H}-\mathrm{BIPM})(\mathrm{L})_{2}$ compounds featuring 
relatively large donors, such as $\left[\mathrm{Y}(\mathrm{H}-\mathrm{BIPM})\left\{\mathrm{OC}\left(\mathrm{CH}_{2} \mathrm{SiMe}_{3}\right) \mathrm{Ph}_{2}\right\} \mathrm{O}-\left\{\left(\mathrm{CPh}_{2}\right)(\mathrm{OCPh}) \mathrm{C}_{6} \mathrm{H}_{4}\right\}\right]$ $[2.726(4) \AA] .{ }^{25}$ Comparatively, the $\mathrm{Y}-\mathrm{C}_{\text {cyclometalate }}$ interactions in 3-5 [3: 2.404(6) $\AA$; 4: 2.394(10) $\AA$; 5: $2.352(6) \AA]$ are all significantly shorter than their corresponding $\mathrm{Y}-\mathrm{C}_{\mathrm{H}-\mathrm{BIPM}}$ bonds. A reasonable explanation for this is the absence of steric constraints around the carbon donor of the cyclometalated silylamide ligand, thus enabling a closer contact between the carbanion and the metal center.

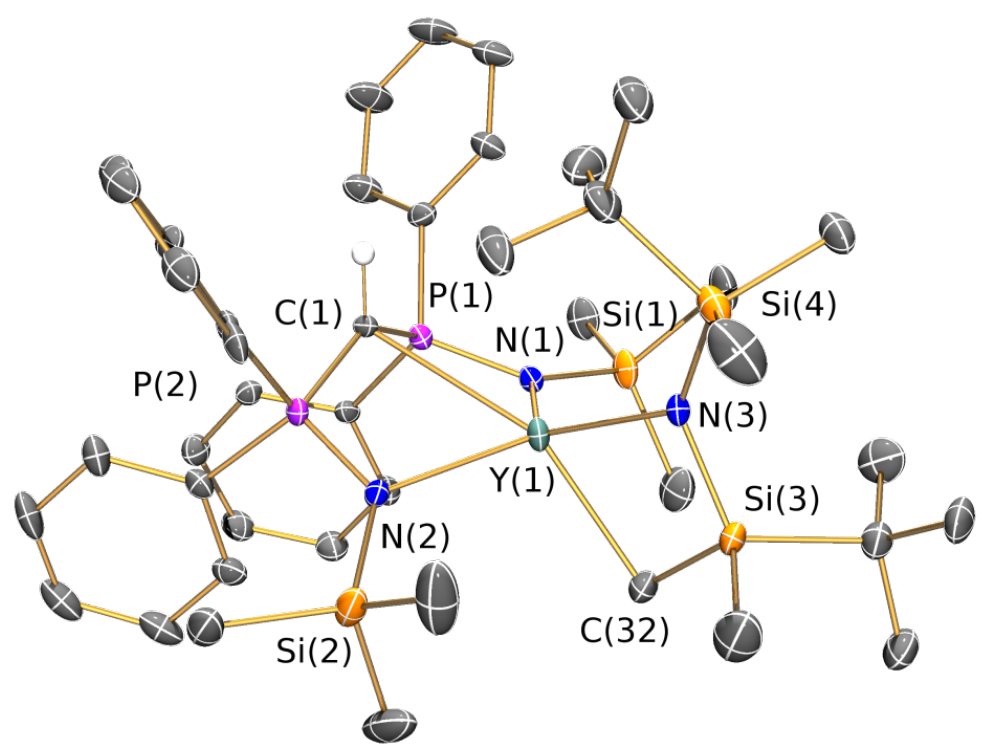

Figure 4. Molecular structure of $\mathbf{3}$ with selective atom labelling, with displacement ellipsoids set at the $30 \%$ probability level; hydrogen atoms have been omitted for clarity with the exception of the one bound to atom $\mathrm{C}(1)$. 


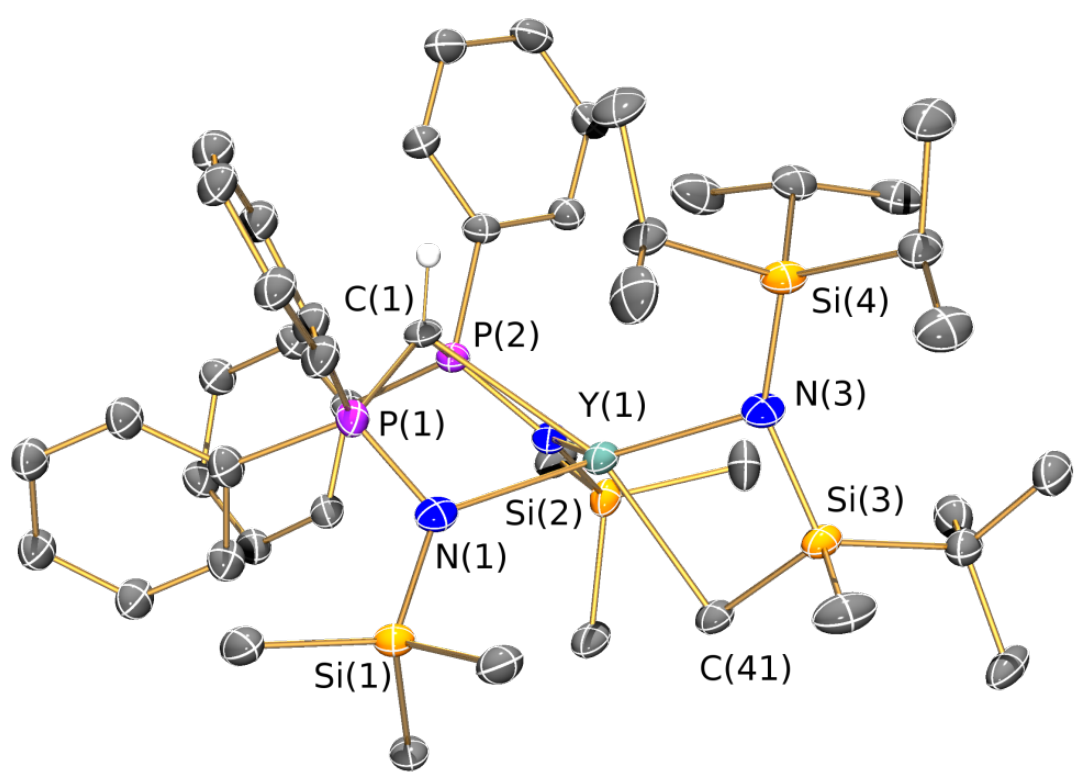

Figure 5. Molecular structure of $\mathbf{4}$ with selective atom labelling, with displacement ellipsoids set at the $30 \%$ probability level; hydrogen atoms have been omitted for clarity with the exception of the one bound to atom $\mathrm{C}(1)$.

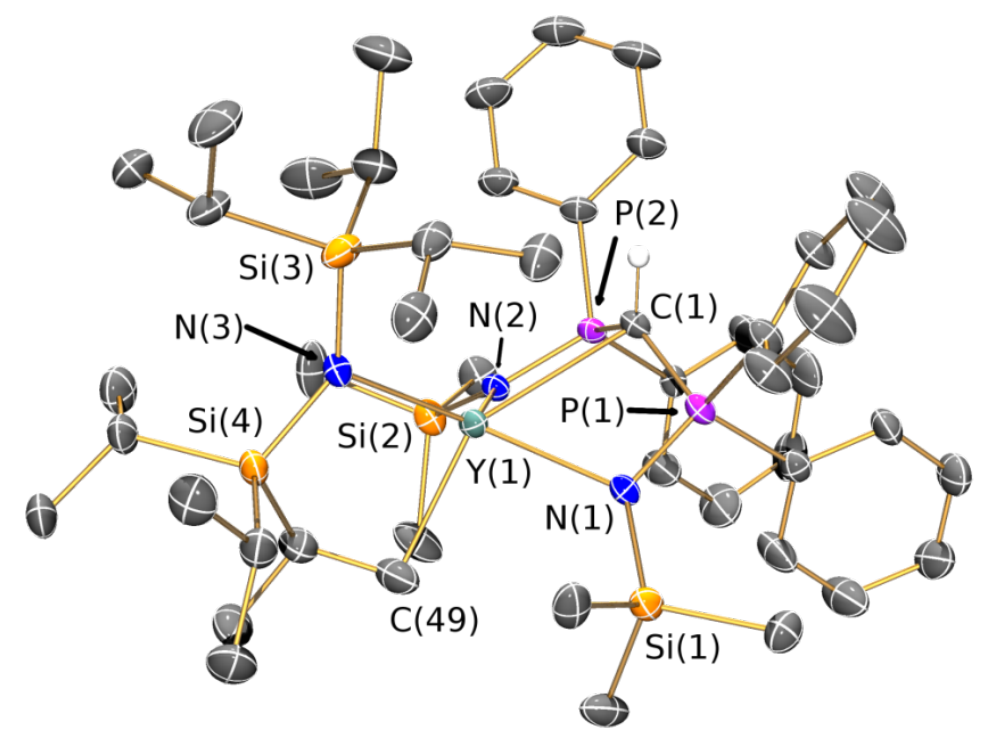

Figure 6. Molecular structure of 5 with selective atom labelling, with displacement ellipsoids set at the $30 \%$ probability level; hydrogen atoms have been omitted for clarity with the exception of the one bound to atom $\mathrm{C}(1)$.

Despite the increased steric requirements of $\mathrm{N}^{\dagger \dagger}$ compared to $\mathrm{N}^{* \dagger}$, the $\mathrm{Y}-\mathrm{N}$ distance in 4 is comparable to that in 5. This observation can be attributed to the differing cyclometalate ring strains 
in operation in these complexes, which is exemplified by the $\mathrm{Y}-\mathrm{C}-\mathrm{Si}-\mathrm{N}$ torsion angles. In 3 and 4 the 4-membered cyclometalate ring is almost planar, giving a strained system [Y-C-Si-N: 7.3(3) ${ }^{\circ}$ (3); 5.8(4) ${ }^{\circ}(4)$ ], whilst in 5 the 5-membered ring is less strained and has a much wider torsion angle $\left[\mathrm{Y}-\mathrm{C}-\mathrm{C}-\mathrm{Si}-\mathrm{N}: 58.0(2)^{\circ}\right]$. This aspect is further supported by the relatively short $\mathrm{Y}-\mathrm{C}_{\text {cyclometalate }}$ distance in $\mathbf{5}$ compared with $\mathbf{3}$ and $\mathbf{4}$. Four-membered Y(III) N" metalacycles have been previously reported, ${ }^{37-39}$ such as $\left[\mathrm{K}\left(18\right.\right.$-crown-6)(THF)(toluene)] $\left[\mathrm{Y}\left\{\mathrm{N}\left(\mathrm{SiMe}_{3}\right)_{2}\right\}\left\{\mathrm{N}\left(\mathrm{SiMe}_{3}\right)\left(\mathrm{SiMe}_{2} \mathrm{CH}_{2}\right)-\kappa^{2}-\right.\right.$ $N, C\}],{ }^{37}$ which features a near-planar metalacycle $\left[\mathrm{Y}-\mathrm{C}-\mathrm{Si}-\mathrm{N}=5.8^{\circ}\right.$ and $\left.9.2^{\circ}\right]$ and similar $\mathrm{Y}-$ $\mathrm{C}_{\text {cyclometalate }}$ distances [2.428(9)-2.503(4) $\AA$ ] to those of complexes 3 and 4. Cyclometalation of the $\mathrm{NSi}^{t} \mathrm{BuMe}_{2}$ fragment has been previously shown to occur; for example in the tris(amido) complexes $\left[\mathrm{M}\left\{\mathrm{N}\left(\mathrm{CH}_{2} \mathrm{CH}_{2} \mathrm{NSi}^{t} \mathrm{BuMe}_{2}\right)_{2}\left(\mathrm{CH}_{2} \mathrm{CH}_{2} \mathrm{NSi}^{t} \mathrm{BuMeCH}_{2}\right)\right\}\right](\mathrm{M}=\mathrm{Zr}, \mathrm{Th}, \mathrm{U})^{40-42}$ the 4-membered cyclometalate rings display a similar level of strain [e.g. $\mathrm{Zr}-\mathrm{C}-\mathrm{Si}-\mathrm{N}=6.6(3)^{\circ} ; \mathrm{U}-\mathrm{C}-\mathrm{Si}-\mathrm{N}=6.1(3)^{\circ}$ and $7.5(3)^{\circ}$ ] to that exhibited by 3 and 4 . Furthermore, some of us have previously shown that the $\mathrm{NSi}^{i} \mathrm{Pr}_{3}$ fragments in $\left[\mathrm{An}\left\{\mathrm{N}\left(\mathrm{CH}_{2} \mathrm{CH}_{2} \mathrm{NSi}^{i} \mathrm{Pr}_{3}\right)_{2}-\left(\mathrm{CH}_{2} \mathrm{CH}_{2} \mathrm{NSi}^{i} \operatorname{Pr}_{2} \mathrm{CHMeCH}_{2}\right)\right\}\right](\mathrm{An}=\mathrm{Th}, \mathrm{U})$ can thermolytically readily $\mathrm{C}-\mathrm{H}$ activate at one of the methyl groups, thus forming 5-membered metalacycles [e.g. U-C $-\mathrm{C}-\mathrm{Si}=39.78^{\circ} ; \mathrm{U}-\mathrm{C}-\mathrm{C}-\mathrm{Si}=40.9^{\circ}$ ] that are analogous to those observed for 5 . $^{43}$ 
Table 1. Selected bond distances $(\AA)$ and angles $\left({ }^{\circ}\right)$ for 2-5.

\begin{tabular}{|c|c|c|c|c|c|}
\hline & 2 & 3 & 4 & $5 \cdot\left(\mathrm{C}_{6} \mathrm{H}_{6}\right)$ & $5 \cdot\left(\mathrm{C}_{7} \mathrm{H}_{8}\right)$ \\
\hline $\mathrm{Y}=\mathrm{C}_{\mathrm{BIPM}}$ & $2.357(3)$ & - & - & - & - \\
\hline $\mathrm{Y}-\mathrm{C}_{\mathrm{H}-\mathrm{BIPM}}$ & - & $2.773(5)$ & $2.729(9)$ & $2.713(3)$ & $2.706(4)$ \\
\hline $\mathrm{Y}-\mathrm{N}_{\mathrm{BIPM}}$ & $\begin{array}{l}2.141(2) \\
2.425(2)\end{array}$ & $\begin{array}{l}2.357(5) \\
2.360(5)\end{array}$ & $\begin{array}{c}2.361(9) \\
2.403(10)\end{array}$ & $\begin{array}{l}2.378(2) \\
2.395(2)\end{array}$ & $\begin{array}{l}2.389(4) \\
2.393(4)\end{array}$ \\
\hline $\mathrm{Y}-\mathrm{N}_{\text {silylamide }}$ & $2.340(2)$ & $2.221(5)$ & $2.267(8)$ & $2.281(3)$ & $2.282(4)$ \\
\hline $\mathrm{Y}-\mathrm{C}_{\text {cyclometalate }}$ & - & $2.404(6)$ & $2.394(10)$ & $2.362(4)$ & $2.352(6)$ \\
\hline $\mathrm{C}_{\mathrm{BIPM}}-\mathrm{Y}-\mathrm{N}$ & $143.58(9)$ & $130.33(6)$ & $128.6(3)$ & $126.39(9)$ & $128.05(14)$ \\
\hline $\mathrm{P}-\mathrm{C}-\mathrm{P}$ & $169.50(17)$ & $133.0(3)$ & $127.7(5)$ & $130.51(17)$ & $130.7(3)$ \\
\hline
\end{tabular}

\section{CONCLUSION}

Salt elimination/metathesis protocols are suitable for the synthesis of Y(III) BIPM methanediide complexes containing relatively small bis(silyl)amides. However, more sterically demanding aliphatic bis(silyl)amides are prone to cyclometalation and the formation of H-BIPM methanide complexes under the conditions employed. Studies of the decomposition of 2 indicated that cyclometalation and methanide formation to give 3-5 is likely promoted by the loss of THF and the 
resultant coordinative unsaturation of the Y(III) coordination sphere. Therefore, different synthetic methodologies are required for the synthesis of solvent-free $\left[\mathrm{Y}(\mathrm{BIPM})\left(\mathrm{N}^{\mathrm{RR}}\right)\right]$ synthetic targets with the ligands used herein. Nevertheless, this study reinforces previous findings that $\left[\mathrm{Y}(\mathrm{BIPM})(\mathrm{I})(\mathrm{THF})_{2}\right]$ is an appropriate starting material for the synthesis of heteroleptic Y(III) BIPM complexes by salt metathesis reactions; thus other co-ligands with different steric features and donor properties may give highly axial 4-coordinate Ln(III) BIPM complexes in future.

\section{EXPERIMENTAL SECTION}

General methods. All syntheses and manipulations were conducted under argon with rigorous exclusion of oxygen and water using Schlenk line and glove box techniques. Toluene and THF were sparged with argon and passed through columns containing Q-5 and molecular sieves; these were stored over potassium and activated $4 \AA$ molecular sieves respectively. Benzene and hexane were dried by refluxing over potassium and were stored over potassium mirrors. All solvents were degassed before use. $d_{6}$-Benzene was dried by refluxing over $\mathrm{K}$ and was vacuum transferred and degassed by three freeze-pump-thaw cycles before use. [Y(BIPM)(I)(THF) $\left.{ }_{2}\right]{ }^{23 a}$ $\mathrm{KN}^{\prime \prime},{ }^{44} \mathrm{KN}^{* *},{ }^{18} \mathrm{KN}^{* \dagger 17}$ and $\mathrm{KN}^{\dagger \dagger 11}$ were prepared according to literature methods. ${ }^{1} \mathrm{H}(400 \mathrm{MHz})$, ${ }^{1} \mathrm{H}\left\{{ }^{31} \mathrm{P}\right\} \quad(400 \mathrm{MHz}),{ }^{13} \mathrm{C}\left\{{ }^{1} \mathrm{H}\right\} \quad(100 \mathrm{MHz}$ and $125 \mathrm{MHz}),{ }^{29} \mathrm{Si}\left\{{ }^{1} \mathrm{H}\right\} \quad(79 \mathrm{MHz})$ and ${ }^{31} \mathrm{P}\left\{{ }^{1} \mathrm{H}\right\} \quad(162$ MHz) NMR spectra were obtained on an Avance III $400 \mathrm{MHz}$ or $500 \mathrm{MHz}$ spectrometer at $298 \mathrm{~K}$, unless otherwise stated. These were referenced to the solvent used, or to external TMS $\left({ }^{1} \mathrm{H},{ }^{13} \mathrm{C}\right.$, ${ }^{29} \mathrm{Si}$ ), or $\mathrm{H}_{3} \mathrm{PO}_{4} / \mathrm{D}_{2} \mathrm{O}\left({ }^{31} \mathrm{P}\right)$. Fourier transform infrared spectra were recorded as Nujol mulls in $\mathrm{KBr}$ discs using a Shimadzu IRAffinity-1S spectrometer. Elemental analyses were performed by Mrs Anne Davies and Mr Martin Jennings at The University of Manchester, U.K.

Synthesis of $\left[\mathbf{Y}(\mathbf{B I P M})\left(\mathbf{N}^{\prime \prime}\right)(\mathbf{T H F})\right] \mathbf{( 1 )}$. Toluene $(15 \mathrm{~mL})$ was added to a pre-cooled mixture $\left(-78^{\circ} \mathrm{C}\right)$ of $\left[\mathrm{Y}(\mathrm{BIPM})(\mathrm{I})(\mathrm{THF})_{2}\right](1.83 \mathrm{~g}, 2 \mathrm{mmol})$ and $\mathrm{KN}^{\prime \prime}(0.40 \mathrm{~g}, 2 \mathrm{mmol})$. The reaction 
was warmed slowly to room temperature and the resultant yellow mixture stirred for $16 \mathrm{~h}$. The reaction mixture was filtered and volatiles removed in vacuo. The residual beige solid was washed with hexane (2x10 mL), affording 1 as a microcrystalline solid (1.544 g, 89\%). Colorless crystals suitable for X-ray diffraction were obtained from a concentrated toluene solution $(\mathrm{ca} .4 \mathrm{~mL})$ at $8{ }^{\circ} \mathrm{C}$ overnight. Anal Calcd for $\mathrm{C}_{41} \mathrm{H}_{64} \mathrm{~N}_{3} \mathrm{OP}_{2} \mathrm{Si}_{4} \mathrm{Y}$ : C 56.08, H 7.35, N 4.79. Found: C 54.70, H 7.17, N 4.89. Low carbon values were obtained reproducibly due to silicon-carbide formation; this has been previously seen for silicon-rich organometallic complexes. ${ }^{45,46}{ }^{1} \mathrm{H}$ NMR $\left(d_{6}\right.$-benzene, $\left.298 \mathrm{~K}\right): \delta=$ 0.23 (s, 18H, BIPM-Si $\left.\left(\mathrm{CH}_{3}\right)_{3}\right), 0.55$ (s, 18H, N"-Si $\left.\left(\mathrm{CH}_{3}\right)_{3}\right), 1.30$ (br, 4H, THF-CH $\mathrm{H}_{2}$ ), 3.99 (br, 4H, THF-OCH$\left.H_{2}\right), 6.72-7.35(\mathrm{br}, 12 \mathrm{H}, \mathrm{Ar}-H), 7.96(\mathrm{br}, 8 \mathrm{H}, \mathrm{Ar}-H) \mathrm{ppm} .{ }^{13} \mathrm{C}\left\{{ }^{1} \mathrm{H}\right\}$ NMR $\left(d_{6}\right.$-benzene, 298 $\mathrm{K}): \delta=5.04(\mathrm{BIPM}-\mathrm{SiMe}), 6.08\left(\mathrm{~N}^{\prime \prime}-\mathrm{Si} M e_{3}\right), 24.96\left(\mathrm{THF}-\mathrm{CH}_{2}\right), 57.85\left(\mathrm{td}, J_{\mathrm{CP}}=180 \mathrm{~Hz}, J_{\mathrm{CY}}=5\right.$ Hz, YCP 2 ), $71.96\left(\mathrm{THF}_{-} \mathrm{OCH}_{2}\right.$ ), 127.49 (br, Ar-C), 129.42 (br, Ar-CH), 131.85 (br, Ar-CH) ppm. ${ }^{29} \mathrm{Si}\left\{{ }^{1} \mathrm{H}\right\}$ NMR $\left(d_{6}\right.$-benzene, $\left.298 \mathrm{~K}\right): \delta=-10.57\left(\mathrm{~N}^{\prime \prime}-\mathrm{SiMe}_{3}\right),-9.25$ (br, BIPM-NSiMe $)$ ppm. ${ }^{31} \mathrm{P}\left\{{ }^{1} \mathrm{H}\right\}$ NMR $\left(d_{6}\right.$-benzene, $\left.298 \mathrm{~K}\right): 5.50\left(\mathrm{~d},{ }^{2} J_{\mathrm{PY}}=15 \mathrm{~Hz}, \mathrm{YCPN}\right) \mathrm{ppm}$. FTIR $\left(\right.$ Nujol, $\left.\mathrm{cm}^{-1}\right): \tilde{v}=$ $1956(\mathrm{w}), 1898(\mathrm{w}), 1670(\mathrm{w}), 1589(\mathrm{w}), 1435$ (s), 1304 (m), 1258 (s, sh.), 1177 (w), 1103 (s), 1050 (br. s), 980 (s), 826 (br. s), 748 (m, sh.), 725 (w), 710 (m), 694 (m), 667 (m), 640 (w), 602 (s).

Synthesis of $\left[\mathbf{Y}(\mathbf{B I P M})\left\{\mathbf{N}\left(\mathbf{S i}^{\mathrm{t}} \mathrm{BuMe}_{2}\right)_{2}\right\}(\mathbf{T H F})\right]$ (2). Toluene $(15 \mathrm{~mL})$ was added to a precooled mixture $\left(-78{ }^{\circ} \mathrm{C}\right)$ of $\left[\mathrm{Y}(\mathrm{BIPM})(\mathrm{I})(\mathrm{THF})_{2}\right](1.83 \mathrm{~g}, 2 \mathrm{mmol})$ and $\mathrm{KN} * *(0.48 \mathrm{~g}, 2 \mathrm{mmol})$. The reaction was warmed slowly to room temperature and the resultant yellow mixture stirred for $16 \mathrm{~h}$. The reaction mixture was filtered and reduced in volume $(c a .4 \mathrm{~mL})$ and stored at $0{ }^{\circ} \mathrm{C}$ overnight, affording 2 as colorless crystals $(0.950 \mathrm{~g}, 49 \%)$. Anal Calcd for $\mathrm{C}_{47} \mathrm{H}_{76} \mathrm{~N}_{3} \mathrm{OP}_{2} \mathrm{Si}_{4} \mathrm{Y}$ : C 58.69, H 7.96, N 4.37. Found: C 59.07, H 8.02, N 4.38. ${ }^{1} \mathrm{H}$ NMR $\left(d_{6}\right.$-benzene, $\left.298 \mathrm{~K}\right): \delta=0.15(\mathrm{~s}, 18 \mathrm{H}$, BIPM-SiMe $), 0.54$ (s, 12H, N**-SiMe $), 1.19$ (s, 18H, N**-CMe 3 ), 1.45 (m, 4H, THF-CH ( $_{2}$ ), 3.57 (m, 4H, THF-OCH $H_{2}$ ), 6.96-7.01 (br m, 12H, Ar-CH), 7.50 (br m, 8H, Ar-CH) ppm. ${ }^{13} \mathrm{C}\left\{{ }^{1} \mathrm{H}\right\}$ NMR $\left(d_{6}\right.$-benzene, $\left.298 \mathrm{~K}\right): \delta=2.93\left(\mathrm{~N}^{* *} *_{-} \mathrm{SiMe}_{2} \mathrm{CMe}_{3}\right), 5.52$ (br, BIPM-SiMe $), 21.15\left(\mathrm{~N}^{* *} *_{-}\right.$ $\mathrm{SiMe}_{2} \mathrm{CMe}_{3}$ ), $25.92\left(\mathrm{THF}-\mathrm{CH}_{2}\right), 26.46\left(\mathrm{~N}^{* *}-\mathrm{SiMe}_{2} \mathrm{CMe}_{3}\right), 29.33\left(\mathrm{~N}^{* *}-\mathrm{SiMe}_{2} \mathrm{CMe}_{3}\right), 63.37$ (td, $J_{\mathrm{CP}}$ $\left.=166 \mathrm{~Hz}, J_{\mathrm{CY}}=8 \mathrm{~Hz}, \mathrm{YCP}_{2}\right), 67.95\left(\mathrm{THF}-\mathrm{OCH}_{2}\right), 127.36\left(\mathrm{t}, J_{\mathrm{CP}}=6 \mathrm{~Hz}, \mathrm{Ar}-\mathrm{CH}\right), 129.20(\mathrm{Ar}-C \mathrm{H})$, 
132.05 (br, Ar-CH), $140.53\left(\mathrm{t}, J_{\mathrm{CP}}=46 \mathrm{~Hz}, \mathrm{Ar}-C\right) \mathrm{ppm} .{ }^{29} \mathrm{Si}\left\{{ }^{1} \mathrm{H}\right\}$ NMR $\left(d_{6}\right.$-benzene, $\left.298 \mathrm{~K}\right): \delta=$ $-21.90\left(\mathrm{Si}^{t} \mathrm{BuMe}_{2}\right),-8.11,-6.82(\mathrm{~m}, \mathrm{BIPM}-\mathrm{NSiMe})$ ppm. ${ }^{31} \mathrm{P}\left\{{ }^{1} \mathrm{H}\right\}$ NMR $\left(d_{6}\right.$-benzene, $\left.298 \mathrm{~K}\right): \delta=$ $7.55\left(\mathrm{~d},{ }^{2} J_{\mathrm{PY}}=15 \mathrm{~Hz}, \mathrm{YCPN}\right)$ ppm. FTIR (Nujol, $\left.\mathrm{cm}^{-1}\right): \tilde{v}=2019(\mathrm{w}), 1954(\mathrm{w}), 1907(\mathrm{w}), 1823$ (w), $1767(w), 1666(w), 1589(w), 1433(\mathrm{~m}), 1304(\mathrm{w}), 1244(\mathrm{~s}), 1177(\mathrm{w}), 1101$ (s), 1022 (br. s), 827 (br. s), 789 (w), $772(\mathrm{w}), 746(\mathrm{w}), 694(\mathrm{w}), 675(\mathrm{~m}), 663$ (m), $640(\mathrm{~m}), 604(\mathrm{~m})$.

Synthesis of $\left[\mathbf{Y}(\mathbf{H}-\mathbf{B I P M})\left\{\mathbf{N}\left(\mathrm{Si}^{\mathrm{i}} \mathbf{P r}_{3}\right)\left(\mathrm{Si}^{\mathrm{t}} \mathbf{B u M e C H}_{2}\right)-\kappa^{2}-\mathbf{N}, \mathbf{C}\right\}\right]$ (4). Toluene $(15 \mathrm{~mL})$ was added to a pre-cooled mixture $\left(-78{ }^{\circ} \mathrm{C}\right)$ of $\left[\mathrm{Y}(\mathrm{BIPM})(\mathrm{I})(\mathrm{THF})_{2}\right](1.83 \mathrm{~g}, 2 \mathrm{mmol})$ and $\mathrm{KN}^{*^{\dagger}}(0.65 \mathrm{~g}$, $2 \mathrm{mmol}$ ). The reaction was warmed slowly to room temperature and the resultant yellow mixture stirred for $16 \mathrm{~h}$. The reaction mixture was filtered and reduced in volume (ca. $4 \mathrm{~mL})$ and stored at 8 ${ }^{\circ} \mathrm{C}$ overnight, affording 4 as colorless crystals (1.082 g, $58 \%$ ). Anal Calcd for $\mathrm{C}_{46} \mathrm{H}_{74} \mathrm{~N}_{3} \mathrm{P}_{2} \mathrm{Si}_{4} \mathrm{Y} \cdot 0.2 \mathrm{C}_{7} \mathrm{H}_{8}$ : C 59.88, H 8.01, N 4.42. Found: C 59.90, H 8.10, N 4.31. ${ }^{1} \mathrm{H}$ NMR $\left(d_{6}{ }^{-}\right.$ benzene, $298 \mathrm{~K}$ ): $\delta=0.37$ (s, 9H, BIPM-SiMe $), 0.42$ (s, 9H, BIPM-SiMe $), 0.54$ (m, 1H, BIPM$\mathrm{CHP} 2), 0.65\left(\mathrm{~m}, 2 \mathrm{H}, \mathrm{N}^{* \dagger}-\mathrm{Si}\left(\mathrm{CH}_{2}\right)\left(\mathrm{CH}_{3}\right)\left[\mathrm{C}\left(\mathrm{CH}_{3}\right)\right]\right), 0.83\left(\mathrm{~s}, 3 \mathrm{H}, \mathrm{N}^{* \dagger}-\mathrm{Si}\left(\mathrm{CH}_{2}\right)\left(\mathrm{CH}_{3}\right)\left[\mathrm{C}_{\left.\left.\left(\mathrm{CH}_{3}\right)\right]\right),} 1.09\right.\right.$

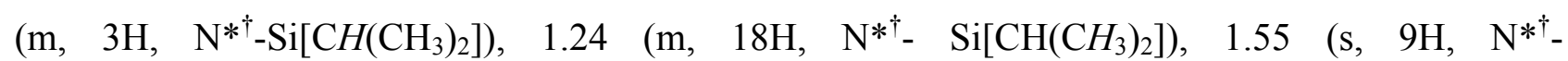
$\left.\mathrm{Si}\left(\mathrm{CH}_{2}\right)\left(\mathrm{CH}_{3}\right)\left[\mathrm{C}\left(\mathrm{CH}_{3}\right)\right]\right), 6.71(\mathrm{~m}, 8 \mathrm{H}, \mathrm{Ar}-\mathrm{CH}), 7.06(\mathrm{~m}, 2 \mathrm{H}, \mathrm{Ar}-\mathrm{CH}+$ toluene), 7.23 (m, 4H, Ar$\mathrm{CH}), 7.37(\mathrm{~m}, 1 \mathrm{H}, \mathrm{Ar}-\mathrm{CH}), 7.75(\mathrm{~m}, 4 \mathrm{H}, \mathrm{Ar}-\mathrm{C} H), 7.89(\mathrm{~m}, 1 \mathrm{H}, \mathrm{Ar}-\mathrm{CH})$ ppm. ${ }^{13} \mathrm{C}\left\{{ }^{1} \mathrm{H}\right\} \mathrm{NMR}\left(d_{6^{-}}\right.$ benzene, $298 \mathrm{~K}): \delta=5.33\left(\mathrm{~d},{ }^{3} J_{\mathrm{CP}}=3.9 \mathrm{~Hz}, \mathrm{BIPM}-\mathrm{Si} M e_{3}\right), 5.45\left(\mathrm{~d},{ }^{3} J_{\mathrm{CP}}=3.9 \mathrm{~Hz}, \mathrm{BIPM}-\mathrm{Si}_{2} e_{3}\right)$, $18.23\left(\mathrm{~N}^{* \dagger}-\mathrm{Si}\left[\mathrm{CH}\left(\mathrm{CH}_{3}\right)_{2}\right]\right), 18.96\left(\mathrm{~N}^{* \dagger}-\mathrm{Si}\left[\mathrm{CH}\left(\mathrm{CH}_{3}\right)_{2}\right]\right), 19.23\left(\mathrm{~N}^{* \dagger}-\mathrm{Si}\left[\mathrm{CH}\left(\mathrm{CH}_{3}\right)_{2}\right]\right), 20.70\left(\mathrm{~N}^{* \dagger^{\dagger}}\right.$ $\left.\mathrm{Si}\left[\mathrm{CH}\left(\mathrm{CH}_{3}\right)_{2}\right]\right), 20.95\left(\mathrm{~d},{ }^{3} \mathrm{~J}_{\mathrm{CY}}=4.9 \mathrm{~Hz}, \mathrm{~N}^{* \dagger}-\mathrm{Si}\left[\mathrm{CH}\left(\mathrm{CH}_{3}\right)_{2}\right]\right), 20.95\left(\mathrm{~N}^{* \dagger}-\mathrm{Si}\left[\mathrm{CH}\left(\mathrm{CH}_{3}\right)_{2}\right]\right), 21.82(\mathrm{~d}$, $\left.{ }^{3} J_{\mathrm{CY}}=2.0 \mathrm{~Hz}, \mathrm{~N}^{* \dagger}-\mathrm{Si}\left(\mathrm{CH}_{2}\right)\left(\mathrm{CH}_{3}\right)\left[C\left(\mathrm{CH}_{3}\right)\right]\right), 29.47\left(\mathrm{~N}^{* \dagger}-\mathrm{Si}\left(\mathrm{CH}_{2}\right)\left(\mathrm{CH}_{3}\right)\left[\mathrm{C}\left(\mathrm{CH}_{3}\right)\right]\right), 36.13\left(\mathrm{~d}, J_{\mathrm{CY}}=39\right.$ $\mathrm{Hz}, \mathrm{N}^{* \dagger}-\mathrm{Si}\left(\mathrm{CH}_{2}\right)\left(\mathrm{CH}_{3}\right)\left[\mathrm{C}\left(\mathrm{CH}_{3}\right)\right], 128.30(\mathrm{~m}, \mathrm{Ar}-\mathrm{CH}), 128.92(\mathrm{Ar}-\mathrm{CH}), 130.52(\mathrm{~m}, \mathrm{Ar}-\mathrm{CH}), 130.82$ (m, Ar-CH), 131.60 (m, Ar-CH), $132.18(\mathrm{Ar}-\mathrm{CH}), 132.28(\mathrm{Ar}-\mathrm{CH}), 133.31(\mathrm{Ar}-\mathrm{C}), 134.20(\mathrm{Ar}-\mathrm{C})$ ppm. YCHP 2 not observed. ${ }^{29} \mathrm{Si}\left\{{ }^{1} \mathrm{H}\right\}$ NMR $\left(d_{6}\right.$-benzene, $\left.298 \mathrm{~K}\right): \delta=-21.82\left(\mathrm{Si}^{t} \mathrm{BuMe}_{2}\right),-19.23$ $\left(S i^{t} \mathrm{BuMe}_{2}\right),-10.48,-5.14$ ppm. ${ }^{31} \mathrm{P}\left\{{ }^{1} \mathrm{H}\right\}$ NMR $\left(d_{6}\right.$-benzene, $\left.298 \mathrm{~K}\right): \delta=10.37(\mathrm{~m}, \mathrm{BIPM}-\mathrm{YCH} P \mathrm{~N})$, 18.77 (m, BIPM-YCHPN), 19.57 (m, BIPM-YCHPN), 22.62 (m, BIPM-YCHPN) ppm. FTIR 
(Nujol, $\mathrm{cm}^{-1}$ ): $\tilde{v}=1960$ (w), 1308 (w), 1250 (s), $1211(\mathrm{~m}), 1173$ (w), 1123 (s), 1069 (s), 1015 (s), 976 (m), 837 (s), 764 (m), 725 (m), 694 (m), 660 (m), 636 (w), 606 (m).

Synthesis of $\left[\mathbf{Y}(\mathbf{H}-\mathrm{BIPM})\left\{\mathrm{N}\left(\mathrm{Si}^{\mathrm{i}} \operatorname{Pr}_{3}\right)\left[\mathrm{Si}^{\mathrm{i}} \operatorname{Pr}_{2}\left(\mathrm{CHCH}_{3} \mathrm{CH}_{2}\right)\right]-\mathrm{K}^{2}-\mathrm{N}, \mathrm{C}\right\}\right](5)$. Benzene $(10 \mathrm{~mL})$ was added to a pre-cooled mixture $\left(0^{\circ} \mathrm{C}\right)$ of $\left[\mathrm{Y}(\mathrm{BIPM})(\mathrm{I})(\mathrm{THF})_{2}\right](1.83 \mathrm{~g}, 2 \mathrm{mmol})$ and $\mathrm{KN}^{\dagger \dagger}(0.75$ g, $2 \mathrm{mmol}$ ). The reaction was warmed slowly to room temperature and the resultant red mixture stirred for $16 \mathrm{~h}$. The reaction mixture was filtered and reduced in volume (ca. $4 \mathrm{~mL}$ ) and stored at 8 ${ }^{\circ} \mathrm{C}$ overnight, affording 5 as colorless crystals; multiple crystalline crops were obtained $(0.786 \mathrm{~g}, 40$ \%). Anal Calcd for $\mathrm{C}_{49} \mathrm{H}_{80} \mathrm{~N}_{3} \mathrm{P}_{2} \mathrm{Si}_{4} \mathrm{Y} \cdot 0.8 \mathrm{C}_{6} \mathrm{H}_{6}$ : C 62.32, H 8.24, N 4.05. Found: C 62.01, H 8.40, N 3.96. ${ }^{1} \mathrm{H}$ NMR $\left(d_{6}\right.$-benzene, $\left.298 \mathrm{~K}\right): \delta=0.38\left(\mathrm{~s}, 9 \mathrm{H}, \mathrm{Si}\left(\mathrm{CH}_{3}\right)_{3}\right), 0.49\left(\mathrm{~s}, 9 \mathrm{H}, \mathrm{Si}\left(\mathrm{CH}_{3}\right)_{3}\right), 0.74(\mathrm{~m}, 1 \mathrm{H}$, BIPM-CHP 2$), 0.91\left(\mathrm{~m}, 3 \mathrm{H}, \mathrm{N}^{\dagger \dagger}-\mathrm{Si}\left[\mathrm{CH}\left(\mathrm{CH}_{3}\right)_{2}\right]_{3}\right), 1.08\left(\mathrm{~d},{ }^{3} \mathrm{~J}_{\mathrm{HH}}=7.3 \mathrm{~Hz}, 9 \mathrm{H}, \mathrm{N}^{\dagger \dagger}-\mathrm{Si}\left[\mathrm{CH}\left(\mathrm{CH}_{3}\right)_{2}\right]\right)$, $1.20\left(\mathrm{~d},{ }^{3} J_{\mathrm{HH}}=7.3 \mathrm{~Hz}, 9 \mathrm{H}, \mathrm{N}^{\dagger \dagger}-\mathrm{Si}\left[\mathrm{CH}\left(\mathrm{CH}_{3}\right)_{2}\right]_{3}\right), 1.25\left(\mathrm{~m}, 2 \mathrm{H}, \mathrm{Si}\left[\mathrm{CH}\left(\mathrm{CH}_{3}\right)_{2}\right]_{2}\left[\mathrm{CH}\left(\mathrm{CH}_{3}\right)\left(\mathrm{CH}_{2}\right)\right]\right) 1.33$ (m, $\left.12 \mathrm{H}, \mathrm{N}^{\dagger \dagger}-\mathrm{Si}\left[\mathrm{CH}\left(\mathrm{CH}_{3}\right)_{2}\right]_{2}\left[\mathrm{CH}\left(\mathrm{CH}_{3}\right)\left(\mathrm{CH}_{2}\right)\right]+\mathrm{N}^{\dagger \dagger}-\mathrm{Si}\left[\mathrm{CH}\left(\mathrm{CH}_{3}\right)_{2}\right]_{2}\left[\mathrm{CH}\left(\mathrm{CH}_{3}\right)\left(\mathrm{CH}_{2}\right)\right]\right), 1.46(\mathrm{~m}, 2 \mathrm{H}$, $\left.\mathrm{Si}\left[\mathrm{CH}\left(\mathrm{CH}_{3}\right)_{2}\right]_{2}\left[\mathrm{CH}\left(\mathrm{CH}_{3}\right)\left(\mathrm{CH}_{2}\right)\right]\right), \quad 1.85\left(\mathrm{~m}, 1 \mathrm{H}, \mathrm{Si}\left[\mathrm{CH}\left(\mathrm{CH}_{3}\right)_{2}\right]_{2}\left[\mathrm{CH}\left(\mathrm{CH}_{3}\right)\left(\mathrm{CH}_{2}\right)\right]\right), 2.01\left(\mathrm{~d},{ }^{3} J_{\mathrm{HH}}=\right.$ $\left.6.6 \mathrm{~Hz}, 3 \mathrm{H}, \mathrm{Si}\left[\mathrm{CH}\left(\mathrm{CH}_{3}\right)_{2}\right]_{2}\left[\mathrm{CH}\left(\mathrm{CH}_{3}\right)\left(\mathrm{CH}_{2}\right)\right]\right), 6.64(\mathrm{~m}, 8 \mathrm{H}, \mathrm{Ar}-\mathrm{CH}), 7.28(\mathrm{~m}, 6 \mathrm{H}, \mathrm{Ar}-\mathrm{CH}), 7.66(\mathrm{~m}$, 1H, Ar-CH), $7.87(\mathrm{~m}, 4 \mathrm{H}, \mathrm{Ar}-\mathrm{CH}), 8.05(\mathrm{~m}, 1 \mathrm{H}, \mathrm{Ar}-\mathrm{CH}) \mathrm{ppm} .{ }^{13} \mathrm{C}\left\{{ }^{1} \mathrm{H}\right\}$ NMR $\left(d_{6}\right.$-benzene, $\left.298 \mathrm{~K}\right)$ $\delta: 5.19\left(\mathrm{~d},{ }^{3} J_{\mathrm{CP}}=3.9 \mathrm{~Hz}, \mathrm{BIPM}-\mathrm{Si} M e_{3}\right), 5.79\left(\mathrm{~d},{ }^{3} J_{\mathrm{CP}}=2.9 \mathrm{~Hz}, \mathrm{BIPM}-\mathrm{Si} M e_{3}\right), 19.01\left(\mathrm{~N}^{\dagger \dagger}-\right.$ $\left.\mathrm{Si}\left[\mathrm{CH}\left(\mathrm{CH}_{3}\right)_{2}\right]_{3}\right), 20.64\left(\mathrm{~N}^{\dagger \dagger}-\mathrm{Si}\left[\mathrm{CH}\left(\mathrm{CH}_{3}\right)_{2}\right]_{2}\left[\mathrm{CH}\left(\mathrm{CH}_{3}\right)\left(\mathrm{CH}_{2}\right)\right]\right), 21.01\left(\mathrm{~N}^{\dagger \dagger}-\mathrm{Si}\left[\mathrm{CH}\left(\mathrm{CH}_{3}\right)_{2}\right]_{3}\right), 21.10$ $\left(\mathrm{N}^{\dagger \dagger}-\mathrm{Si}\left[\mathrm{CH}\left(\mathrm{CH}_{3}\right)_{2}\right]_{3}\right), \quad 21.39 \quad\left(\mathrm{~N}^{\dagger \dagger}-\mathrm{Si}\left[\mathrm{CH}\left(\mathrm{CH}_{3}\right)_{2}\right]_{2}\left[\mathrm{CH}\left(\mathrm{CH}_{3}\right)\left(\mathrm{CH}_{2}\right)\right]\right), \quad 21.83 \quad\left(\mathrm{~N}^{\dagger \dagger}-\right.$ $\left.\mathrm{Si}\left[\mathrm{CH}\left(\mathrm{CH}_{3}\right)_{2}\right]_{2}\left[\mathrm{CH}\left(\mathrm{CH}_{3}\right)\left(\mathrm{CH}_{2}\right)\right]\right), \quad 23.83 \quad\left(\mathrm{~N}^{\dagger \dagger}-\mathrm{Si}\left[\mathrm{CH}\left(\mathrm{CH}_{3}\right)_{2}\right]_{2}\left[\mathrm{CH}\left(\mathrm{CH}_{3}\right)\left(\mathrm{CH}_{2}\right)\right]\right), \quad 25.83 \quad\left(\mathrm{~N}^{\dagger \dagger}-\right.$ $\left.\mathrm{Si}\left[\mathrm{CH}\left(\mathrm{CH}_{3}\right)_{2}\right]_{2}\left[\mathrm{CH}\left(\mathrm{CH}_{3}\right)\left(\mathrm{CH}_{2}\right)\right]\right), 54.35\left(\mathrm{~d}, J_{\mathrm{CY}}=47 \mathrm{~Hz}, \mathrm{~N}^{\dagger \dagger}-\mathrm{Si}\left[\mathrm{CH}\left(\mathrm{CH}_{3}\right)_{2}\right]_{2}\left[\mathrm{CH}\left(\mathrm{CH}_{3}\right)\left(\mathrm{CH}_{2}\right)\right]\right)$, 128.85 (m, Ar- $C H$ ), 128.92 (Ar- $C H), 129.44$ (Ar- $C H), 130.10$ (m, Ar- $C H), 130.83$ (Ar-CH), 131.60 (m, Ar-CH), 132.20 (m, Ar- $C H$ ), 132.67 (m, Ar-CH), 135.83 (m, Ar-C), 136.28 (m, Ar-C), 137.23 (m, Ar-C) ppm. YCHP 2 not observed. ${ }^{29} \mathrm{Si}\left\{{ }^{1} \mathrm{H}\right\}$ NMR (d6-benzene, $\left.298 \mathrm{~K}\right): \delta=-5.69,-5.17,-3.93$, $-2.71,-2.31$ ppm. ${ }^{31} \mathrm{P}\left\{{ }^{1} \mathrm{H}\right\}$ NMR (d6-benzene, 298K): $\delta=10.70(\mathrm{~m}, \mathrm{BIPM}-\mathrm{YCH} P \mathrm{~N}), 18.09(\mathrm{~m}$, BIPM-YCHPN), 21.15 (m, BIPM-YCHPN), 22.05 (m, BIPM-YCHPN) ppm. FTIR (Nujol, $\mathrm{cm}^{-1}$ ): 
$\widetilde{v}=1952(\mathrm{w}), 1809(\mathrm{w}), 1589(\mathrm{w}), 1312(\mathrm{w}), 1250(\mathrm{~s}), 1196(\mathrm{~s}), 1115(\mathrm{~s}), 1088(\mathrm{~s}), 1065(\mathrm{~s}), 1000$

(s), $880(\mathrm{~m}), 848(\mathrm{~s}), 764(\mathrm{w}), 737(\mathrm{w}), 694(\mathrm{~s}), 675(\mathrm{~m}), 660(\mathrm{~m}), 613(\mathrm{~s}), 559(\mathrm{w})$.

X-ray crystallography. The crystal data for complexes 1-5 are compiled in the Supporting Information (Tables S1-S2). Crystals of $\mathbf{1 - 3}$ and $\mathbf{5} \cdot \mathbf{C}_{7} \mathbf{H}_{\mathbf{8}}$ were examined using an Agilent Supernova diffractometer, equipped with CCD area detector and mirror-monochromated Mo Ka radiation $(\lambda=0.71073 \AA)$. Crystals of $\mathbf{4}$ and $\mathbf{5} \cdot \mathbf{C}_{\mathbf{6}} \mathbf{H}_{\mathbf{6}}$ were examined using a Bruker Apex II diffractometer, equipped with a CCD area detector and graphite-monochromated $\mathrm{Cu} \mathrm{K} \alpha$ radiation $(\lambda$ $=1.54178 \AA$ ). Intensities were integrated from data recorded on $1^{\circ}$ by $\omega\left(\mathbf{1 - 3}\right.$ and $\left.\mathbf{5} \cdot \mathbf{C}_{7} \mathbf{H}_{\mathbf{8}}\right)$ or $\varphi$ and $\omega\left(4\right.$ and $\left.\mathbf{5} \cdot \mathbf{C}_{6} \mathbf{H}_{6}\right)$ rotation. Cell parameters were refined from the observed positions of all strong reflections in each data set. A Gaussian grid face-indexed (3) or multi-scan (2, 4 and 5) absorption correction with a beam profile was applied. ${ }^{47}$ The structures were solved variously by direct and heavy atom methods using SHELXS ${ }^{48}$ and the datasets were refined by full-matrix least-squares on all unique $F^{2}$ values, with anisotropic displacement parameters for all non-hydrogen atoms, and with constrained riding hydrogen geometries; $U_{\text {iso }}(\mathrm{H})$ was set at 1.2 (1.5 for methyl groups) times $U_{\text {eq }}$ of the parent atom. The largest features in final difference syntheses were close to heavy atoms and were of no chemical significance. CrysAlisPro ${ }^{47}$ was used for control and integration, and SHELX $^{49}$ and OLEX $2^{50}$ were employed for structure solution and refinement. ORTEP-3 $3^{51}$ and POV-Ray ${ }^{52}$ were employed for molecular graphics. CCDC 1551563-1551568 (1-5) contain the supplementary crystal data for this article. These data can be obtained free of charge from the Cambridge Crystallographic Data Centre via www.ccdc.cam.ac.uk/data_request/cif. 


\section{ASSOCIATED CONTENT}

\section{Supporting Information}

NMR spectra, crystallographic tables and crystallographic data (CIF format) for 1-5. This material is available free of charge via the Internet at http://pubs.acs.org.

\section{AUTHOR INFORMATION}

\section{Corresponding Author}

*E-mail steve.liddle@manchester.ac.uk; david.mills@manchester.ac.uk

\section{Notes}

The authors declare no competing financial interest.

\section{ACKNOWLEDGEMENTS}

We thank the Engineering and Physical Sciences Research Council (Grant numbers EP/P002560/1 and EP/M027015/1), European Research Council (CoG612724) and The University of Manchester for funding this work. We would like to acknowledge Dr Conrad Goodwin for assistance with the preparation of silylamide ligand transfer reagents and Dr Ralph Adams for helpful discussions regarding NMR spectroscopy experiments. Additional research data supporting this publication are available from Mendeley Data at doi:10.17632/rnfxgyc92c.1 or from the authors on request. 


\section{REFERENCES}

(1) The Rare Earth Elements: Fundamentals and Applications, Atwood, D. A. Ed.; John Wiley \& Sons Ltd.: Hoboken, NJ, 2012.

(2) Mills, D. P.; Liddle, S. T. Ligand Design in Modern Lanthanide Chemistry, in Ligand Design in Metal Chemistry: Reactivity and Catalysis, Stradiotto, M.; Lundgren, R. J. Eds.; John Wiley \& Sons Ltd.: Hoboken, NJ, 2016; pp 330-363.

(3) Gatteschi, D.; Sessoli, R.; Villain, J. Molecular Nanomagnets, Oxford University Press: Oxford, 2006.

(4) Selected reviews on this topic: (a) Rinehart, J. D.; Long, J. R. Chem. Sci. 2011, 2, 2078-2085.

(b) Woodruff, D. N.; Winpenny, R. E. P; Layfield, R. A. Chem. Rev. 2013, 113, 5110-5148. (c) Liddle, S. T.; van Slageren, J. Chem. Soc. Rev. 2015, 44, 6655-6669. (d) Meng, T.-S.; Jian, S.-D.; Wang, B.-W.; Gao, S. Acc. Chem. Res. 2016, 49, 2381-2389.

(5) (a) Gregson, M.; Chilton, N. F.; Ariciu, A.-M.; Tuna, F.; Crowe, I. F.; Lewis, W.; Blake, A. J.; Collison, D.; McInnes, E. J. L.; Winpenny, R. E. P.; Liddle, S. T. Chem. Sci. 2016, 7, 155-165;

(b) Gregson, M.; Lu, E.; Mills, D. P.; Tuna, F.; McInnes, E. J. L.; Hennig, C.; Scheinost, A. C.; McMaster, J.; Lewis, W.; Blake, A. J.; Kerridge, A.; Liddle, S. T. Nat. Commun. 2017, 8, 14137.

(6) Ding, Y.-S.; Chilton, N. F.; Winpenny, R. E. P.; Zheng, Y.-Z. Angew. Chem. Int. Ed. 2016, $55,16071-16074$.

(7) Chen, Y.-C.; Liu, J.-L.; Ungur, L.; Liu, J.; Li, Q.-W.; Wang, L.F.; Ni, Z.-P.; Chibotaru, L. F.; Chen, X.-M.; Tong, M.-L. J. Am. Chem. Soc. 2016, 138, 2829-2837.

(8) Gupta, S. K.; Rajeshkumar, T.; Rajaraman, G.; Murugavel, R. Chem. Sci. 2016, 7, 51815191.

(9) Liu, J.; Chen, Y.-C.; Liu, J.-L.; Vieru, V.; Ungur, L.; Jia, J.-H.; Chibotaru, L. F.; Lan, Y.; Wernsdorfer, W.; Gao, S.; Chen, X.-M.; Tong, M.-L. J. Am. Chem. Soc. 2016, 138, 5441-5450.

(10) Chilton, N. F.; Collison, D.; McInnes, E. J. L.; Winpenny, R. E. P.; Soncini, A. Nature Commun. 2013, 4, 2551. 
(11) Chilton, N. F.; Goodwin. C. A. P.; Mills, D. P.; Winpenny, R. E. P. Chem. Commun. 2015, $51,101-103$.

(12) Chilton, N. F. Inorg. Chem. 2015, 54, 2097-2099.

(13) (a) Ungur, L.; Chibotaru, L. F. Phys. Chem. Chem. Phys. 2011, 13, 20086-20090; (b) Ungur, L.; Chibotaru, L. F. Inorg. Chem. 2016, 55, 10043-10056.

(14) Aparna, K.; Ferguson, M.; Cavell, R. G. J. Am. Chem. Soc. 2000, 122, 726-727.

(15) (a) Liddle, S. T.; Mills, D. P.; Wooles, A. J. Organomet. Chem. 2010, 36, 29-55. (b) Liddle, S. T.; Mills, D. P.; Wooles, A. J. Chem. Soc. Rev. 2011, 40, 2164-2176; (c) Fustier-Boutignon, M.; Mézailles, N. Top. Organomet. Chem. 2014, 47, 63-128; (d) Gessner, V. H.; Becker, J.; Feichtner, K.-S. Eur. J. Inorg. Chem. 2015, 11, 1841-1859.

(16) Fustier, M.; Le Goff, X.-F.; Lutz, M.; Slootweg, J. C.; Mézailles N. Organometallics 2015, $34,63-72$.

(17) Goodwin, C. A. P.; Joslin, K. C.; Lockyer, S. J.; Formanuik, A.; Morris, G. A.; Ortu, F.; Vitorica-Yrezabal, I. J.; Mills, D. P. Organometallics 2015, 34, 2314-2325.

(18) Goodwin, C. A. P.; Chilton, N. F.; Vettese, G. F.; Pineda, E. M.; Crowe, I. F.; Ziller, J. W.; Winpenny, R. E. P.; Evans, W. J.; Mills, D. P. Inorg. Chem. 2016, 55, 10057-10067.

(19) Goodwin, C. A. P.; Tuna, F.; McInnes, E. J. L.; Liddle, S. T.; McMaster, J.; VitoricaYrezabal, I. J.; Mills, D. P. Chem. -Eur. J. 2014, 14579-14583.

(20) Goodwin, C. A. P; Chilton, N. F.; Natrajan, L. S.; Boulon, M.-E.; Ziller, J. W.; Evans, W. J.; Mills, D. P. Inorg. Chem. 2017, 56, 5959-5970.

(21) Shannon, R. D. Acta Cryst. Sect. A 1976, 32, 751-767.

(22) (a) Lappert, M. F.; Power, P. P.; Sanger, A. R.; Srivastava, R. C. Metal and Metalloid Amides, Ellis Horwood-Wiley: Chichester, 1980. (b) Lappert, M. F.; Protchenko, A.; Power, P. P.; Seeber, A. Metal Amide Chemistry, Wiley: Chichester, 2008.

(23) (a) Mills, D. P.; Wooles, A. J.; McMaster, J.; Lewis, W.; Blake, A. J.; Liddle, S. T. Organometallics 2009, 28, 6771-6776. (b) Wooles, A. J.; Cooper, O. J.; McMaster, J.; Lewis, W.; 
Blake, A. J.; Liddle, S. T. Organometallics 2010, 29, 2315-2321. (c) Gregson, M.; Lu, E.; McMaster, J.; Blake, A. J.; Liddle, S. T. Angew. Chem. Int. Ed. 2013, 52, 13016-13019.

(24) Liddle, S. T.; Mills, D. P.; Gardner, B. M.; McMaster, J.; Jones, C.; Woodul, W. D. Inorg. Chem. 2009, 46, 3520-3522.

(25) Mills, D. P.; Soutar, L.; Lewis, W.; Blake, A. J.; Liddle, S. T. J. Am. Chem. Soc. 2010, 132, $14379-14381$.

(26) Mills, D. P.; Lewis, W.; Blake, A. J.; Liddle, S. T. Organometallics 2013, 32, 1239-1250.

(27) Mills, D. P.; Cooper, O. J.; McMaster, J.; Lewis, W.; Liddle, S. T. Dalton Trans. 2009, 45474555.

(28) Liddle, S. T.; McMaster, J.; Green, J.; Arnold, P. L. Chem. Commun. 2008, 15, 1747-1749.

(29) Mills, D. P.; Soutar, L.; Cooper, O. J.; Lewis, W.; Blake, A. J.; Liddle, S. T. Organometallics 2013, 32, 1251-1264.

(30) El-Nahas, A. M.; von Ragué Schleyer, P. J. Comput. Chem. 1994, 15, 596-626.

(31) Hitchcock, P. B.; Lappert, M. F.; Protchenko, A. V. Chem. Commun. 2005, 951-953.

(32) Johnson, K. R. D.; Hayes, P. Polyhedron 2016, 108, 43-49.

(33) Gardner, B. M.; Lewis, W.; Blake, A. J.; Liddle, S. T. Organometallics 2015, 34, 2386-2394.

(34) Fryzuk, M. D.; Haddad, T. S.; Rettig, S. J. Organometallics 1991, 10, 2026-2036.

(35) Pyykkö, P.; Michiko, A. Chem. -Eur. J. 2008, 15, 186-197.

(36) (a) Jenter, J.; Roesky, P. W.; Ajellal, N.; Guillaume, S. M.; Susperregui, N.; Maron, L. Chem.-Eur. J. 2010, 16, 4629-4638; (b) Gamer, M. T.; Dehnen, S.; Roesky, P. W. Organometallics 2001, 20, 4230-4236; (c) Gamer, M. T.; Roesky, P. W.; Palard, I.; Le Hellaye, M.; Guillaume, S. M. Organometallics 2007, 26, 651-657; (d) Schmid, M.; Ona-Burgos, P.; Guillaume, S. M.; Roesky, P. Dalton Trans. 2015, 44, 12338-12348.

(37) Fang, M.; Bates, J. E.; Lorenz, S. E.; Lee, D. S.; Rego, D. B.; Ziller, J. W.; Furche, F.; Evans, W. J. Inorg. Chem. 2011, 50, 1459-1469.

(38) Niemeyer, M. Inorg. Chem. 2006, 45, 9085-9095. 
(39) Han, F.; Zhang, J.; Yu, W.; Zhang, Z.; Yu, J.; Weng, L.; Zhou, X. Inorg. Chem. 2010, 49, 2793-2798.

(40) Morton, C.; Munslow, I. J.; Sanders, C. J.; Alcock, N. W.; Scott, P. Organometallics 1999, $18,4608-4613$.

(41) Boaretto, R.; Roussel, P.; Kingsley, A. J.; Munslow, I. J.; Sanders, C. J.; Alcock, N. W.; Scott. P. J. Chem. Soc., Chem. Commun. 1999, 1701-1702.

(42) Boaretto, R.; Roussel, P.; Kingsley, A. J.; Munslow, I. J.; Sanders, C. J.; Alcock, N. W.; Scott. P. J. Organomet. Chem. 1999, 591, 174-184.

(43) Gardner, B. M; Cleaves, P. A.; Kefalidis, C. E.; Fang, H.; Maron, L.; Lewis, W.; Blake, A. J.; Liddle, S. T. Chem. Sci. 2014, 5, 2489-2497.

(44) Rabe, G. W.; Kheradmandan, S.; Yap, G. P. A. Inorg. Chem. 1998, 37, 6541-6543.

(45) Hitchcock, P. B.; Lappert, M. F.; Maron, L.; Protchenko, A. V. Angew. Chem. Int. Ed. 2008, 47, 1488-1491.

(46) Goodwin, C. A. P.; Smith, A.; Ortu, F.; Vitorica-Yrezabal, I. J.; Mills, D. P. Dalton Trans. 2016, 45, 6004-6014.

(47) CrysAlis ${ }^{\text {Pro }}$, Agilent Technologies: Yarnton, U.K., 2010.

(48) Sheldrick, G. M. Acta Cryst. Sect. C 2015, 71, 3-8.

(49) Sheldrick, G. M. Acta Cryst. Sect. A 2008, 64, 112-122.

(50) Dolomanov, O. V.; Bourhis, L. J.; Gildea, R. J., Howard; J. A. K., Puschmann, H. J. Appl. Cryst. 2009, 42, 339-341.

(51) Farrugia, L. J. J. Appl. Cryst. 2012, 45, 849-854.

(52) POV-Ray, Persistence of Vision Raytracer Pty. Ltd.: Williamstown, Australia, 2004. 


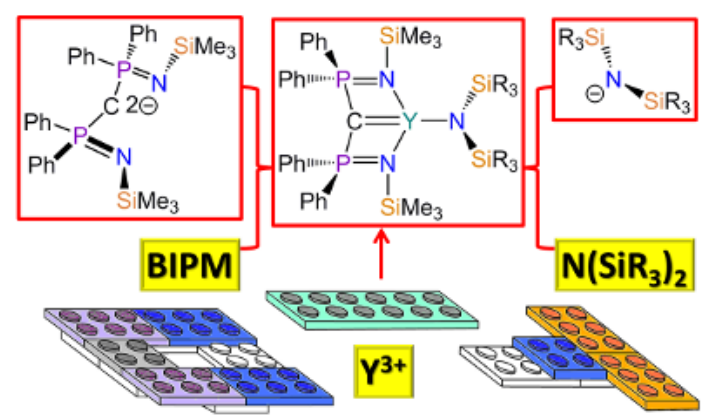

Highly axial yttrium complexes were targeted by employing a combination of methanediide and bis(silyl)amide ligands resulting in $\mathrm{C}-\mathrm{H}$ activation activation at the silyl groups for the more sterically demanding amide ligands. 